
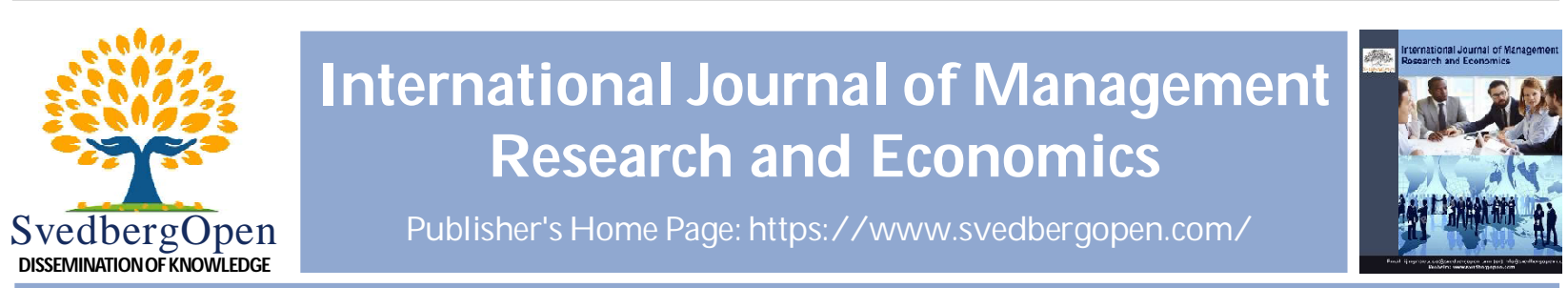

\title{
Stakeholder management in public procurement: Rethinking the engagement strategy for cofinancing in Rivers state, Nigeria
}

Soala Mercy Sam Warmate ${ }^{1 *}$

${ }^{1}$ University of Turin / International Training Centre of the ILO (ITC-ILO), Turin, Italy. E-mail: soalawarmate@yahoo.com

\section{Article Info}

Volume 1, Issue 3, July 2021

Received : 05 February 2021

Accepted : 17 June 2021

Published : 05 July 2021

doi: $10.51483 /$ IJMRE.1.3.2021.22-43

\begin{abstract}
There are many failed public procurements in Nigeria because of undue delays and the abandonment of projects. These projects are wholly funded by the public or co-financed by the Multilateral Development Institutions (MDIs). This anomaly occurs when there is a change of government. Given that the political elites supporting these projects lose political power. And the incoming elites are not adequately engaged or lost interest in the projects because the funds have been siphoned off. Although, the MDIs have robust guidelines on stakeholder engagement. However, their implementation appears inadequate within the procurement life cycle of the projects. Similarly, these guidelines do not anticipate the complex dynamics of a change of government; where the existing priorities and policies get altered due to the shifting interests of the new government. Often, these interests affect the commitment of the government to provide its counterpart fund for the projects. Oddly, the MDIs ought to be familiar with the fact that political interference and policy inconsistencies are the concomitants of change of government in Nigeria-an ever-present political risk. Given the above, rethinking the stakeholder engagement strategy is crucial to ensuring that projects get completed on schedule. The MDIs should increase the level of monitoring and evaluation. And step away from co-financing agreements unless it allows the federal government to provide the counterpart funds on behalf of the states.
\end{abstract}

Keywords: Key stakeholder, Stakeholder engagement strategy, Stakeholder management, Political elites, Multilateral Development Institutions (MDIs), Corruption, Co-financing

(C) 2021 Soala Mercy Sam Warmate. This is an open access article under the CC BY license (https://creativecommons.org/licenses/by/4.0/), which permits unrestricted use, distribution, and reproduction in any medium, provided you give appropriate credit to the original author(s) and the source, provide a link to the Creative Commons license, and indicate if changes were made.

\section{Introduction}

Public procurement plays a fundamental role in the development of the economy of every country. Globally, the annual public contracts are estimated to be US\$9.5 trillion, which is about one-fifth of the world's total economic production. It accounts for about $15-22 \%$ of the gross domestic product in developing countries ${ }^{1}$. A robust stakeholder engagement

\footnotetext{
The World Bank. Procurement for development. https://www.worldbank.org/en/topic/procurement-for-development. Accessed on the May 17, 2020.
}

\footnotetext{
* Corresponding author: Soala Mercy Sam Warmate. University of Turin / International Training Centre of the ILO (ITC-ILO), Turin, Italy. E-mail: soalawarmate@yahoo.com
}

2710-141X/@ 2021. Soala Mercy Sam Warmate. This is an open access article distributed under the Creative Commons Attribution License, which permits unrestricted use, distribution, and reproduction in any medium, provided the original work is properly cited. 
strategy is crucial to implementing these public contracts; because the stakeholder 'can influence the ease with which a project is delivered' ${ }^{2}$. However, identifying and understanding the interests and priorities of various stakeholders in public procurement is critical and an under-explored policy puzzle ${ }^{3}$, that impedes the implementation of stakeholder engagement. In Nigeria, there are a lot of failed public procurements due to political interference and corruption. Including procurements co-financed by the Multilateral Development Institutions (MDIs); where the elites often claim that the MDIs do not engage with them for the project. It is worrisome because the influence or power of these elites is both positional and political. And could be wielded at any stage in the project through coercion, denial of access to material or financial resources, or normative pressure 4 .

Though the MDIs have strategic stakeholder engagement tools and resources. Like the handbook on stakeholder consultation and participation of the Asian Development Bank ${ }^{5}$, the World Bank's Project Procurement Strategy for Development (PPSD) ${ }^{6}$, and the Better Regulation Practices guide by the European Union ${ }^{7}$ amongst others $^{8}$. However, these tools are not effectively used to engage the elites, given that they could exert their positional and political influence negatively - a potential risk to the projects.

It is suggested that the MDIs should step away from co-financing projects with the state governments unless the agreement allows the federal government to contribute the counterpart fund on behalf of the state government. Also, the MDIs should reward good governance with recognition. This strategy will decrease the motivation to engage in corruption and influence peddling. Furthermore, the process of the project selection, award and implementation must be transparent and well-publicized. And civil society organizations should be enlisted to help with the advocacy and monitoring of the projects. While the engagement with the elites should be ongoing and iterative.

\section{Importance of engagement with a political elite - Survey of literature}

In the working paper 'Elite Capture or Capture Elites? Lessons from the 'Counter-elite' and 'Co-opt-elite' Approaches in Bangladesh and Ghana' ${ }^{9}$ Sam Wong wrote:

2 The World Bank (2016). Procurement Guidance: Project Procurement Strategy for Development. Long Form Detailed Guidance July 2016. Published July - First Edition. Page 32 http://pubdocs.worldbank.org/en/847531467334322069/PPSD-Long-

Form.pdf. Accessed on June 20, 2020

3 Yukins, Christopher R. and Schooner, Steven L. (2007). Incrementalism: Eroding the impediments to a global public procurement Market. Georgetown Journal of International Law, 38, 529-576, 2007, GWU Legal Studies Research Paper No. 320, GWU Law School Public Law Research Paper No. 320, https://poseidon01.ssrn.comdelivery.php?ID=26912600209709211 9096107074 102081068122032049015054052117087112094066064121118115101033022034012040098112082070111125122113115 11102905707902109402106706606612206903307503512300407003007602108402511206402611009511006900911 $8077022102117115127118103017 \& \mathrm{EXT}=$ pdf. Accessed on September 9, 2020.

4 S. Vijayanand (2013). Stakeholders and public-private partnerships role in tourism management. page 4 International Journal of Scientific \& Engineering Research 4(2), February, https://www.ijser.org/researchpaper/Stakeholders-and-public-private-partnershipsrole-in-tourism-management.pdf. Accessed on June 15, 2020.

5 The African Development Bank. (2001). The Handbook on Stakeholders Consultation and Participation in ADB Operation. OESU,https://www.afdb.org/fileadmin/uploads/afdb/Documents/Policy-Documents/Handbook\%20 on\%20Stakeholder\%20 Consultaion.pdf. Accessed on June 19, 2020.

6 The World Bank (2016). Procurement Guidance: Project Procurement Strategy for Development. Long Form Detailed Guidance July 2016. Published July, First Edition. pp. 32-35, 93. http://pubdocs. worldbank.org/en/847531467334322069/PPSD-LongForm.pdf. Accessed on June 20, 2020.

7 OECD (2019), Better Regulation Practices across the European Union, OECD Publishing, Paris, https://doi.org/10.1787/ 9789264311732-en. Accessed on June 19, 2020.

8 Marc, Gramberger. (2001). Citizens as Partners. OECD Handbook on Information, Consultation and Public Participation in Policy-making. Organisation for Economic Co-Operation and Development, https://www.internationalbudget.org/wp-content/ uploads/Citizens-as-Partners-OECD-Handbook.pdf; and Inter-American Development Bank 'Guidelines on Consultation and Stakeholder Engagement in IDB Projects', https://publications.iadb.org/publications/english/document/Guidelines-on-Consultationand-Stakeholder-Engagement-in-IDB-Projects.pdf; Asian Development Bank 'Guidance Note on Stakeholder Communication Strategies for Projects in South Asia', https://www.adb.org/sites/default/files/institutional-document/512211/stakeholdercommunication-strategies-guidance-note.pdf. Accessed on June 19, 2020. 
“The 'co-opt-elite' approach ... suggests that cooperation with elites, rather than confrontation, is the solution to alleviating poverty. It asserts that not all elites are bad, and some of them can play a constructive role in community development. It also assumes that power is not a 'zero-sum' game and a pragmatic use of elites' networks and resources channels benefits to poor communities.”

\subsection{Engagement of elites - A conceptual model}

Institutions reflects, the elites must be engaged to advance development; for "evidence shows that to deliver sustainable international development we must be able to understand and work with its politics" ${ }^{10}$. In this part, this paper will offer a conceptual model of engagement with political elites, drawing on both broader research and specifically on elite engagement in development projects.

It is pertinent to describe who these political elites are. The World Bank (WB) aptly described the elites as "actors with a disproportionate influence in the development process as a result of their superior social, political or economic status." 11 In the paper, "Elite Capture or Capture Elites? Lessons from the 'Counter-elite' and 'Co-opt-elite', Approaches in Bangladesh and Ghana", Beard and Phakphian were cited as stating that elites are 'individuals who can exert disproportionate influence over a collective action process ${ }^{\prime 2}$. Furthermore, Musgrave described the elites as: ${ }^{13}$

‘...public officials (elected or appointed) or individuals with demonstrated political affiliation and influence, traditional leaders and their inner circle of advisors and close relatives of both these groups. The political elite exercise power through the decisions they make about expenditure in local or state institutions, their access to international development agencies [the writer's emphasis], and their perceived legitimacy as the duly elected, appointed or traditional authority.'

Kia and Vurasi defined elites as 'those who have decision making power in the state resulting from their statutory or institutional position, or who have influence on policy decisions as a result of their status in the ruling coalition' ${ }^{14}$ From the foregoing definitions, the elites can be described as a group of individuals (elected or appointed) with enormous influence on the decision-making process because of their statutory or positional power or authority under the relevant laws and norms. In Nigeria, the elites control most of the decision-making process concerning the use and management of public resources 15 . Often, they influence the government negatively on the implementation of projects they are not interested in. Including fulfilling financial obligations in a co-financing or counterpart funding arrangement.

9 Wong, Sam. (2010). Elite capture or capture elites? lessons from the 'counter-elite' and 'co-opt-elite' approaches in Bangladesh and Ghana. WIDER Working Paper, No. 2010/82, ISBN 978-92-9230-320-4, The United Nations University World Institute for Development Economics Research (UNU-WIDER), Helsink Page 2. https://www.wider.unu.edu/sites/default/files/wp2010-82.pdf Accessed on November 9, 2020.

10 Department for International Development. The Politics of Poverty: Elites, Citizens and States A Synthesis Paper Findings from ten years of DFID-funded research on Governance and Fragile States 2001-2010. Executive Summary, https://www.oecd.org/derec/ unitedkingdom/48688822.pdf. Accessed on November 9, 2020.

11 The World Bank. (2008). CDD and elite capture: reframing the conversation. Social Development How to Series, 3, 1. February. http:/ /documents1.worldbank.org/curated/zh/397181468137726436/pdf/430830BRI001NO1ing0the0Conversation.pdf. Accessed November 9, 2020.

12 Wong, Sam. (2010. Elite capture or capture elites? lessons from the 'counter-elite' and 'co-opt-elite' approaches in Bangladesh and Ghana. WIDER Working Paper, No. 2010/82, ISBN 978-92-9230-320-4, The United Nations University World Institute for Development Economics Research (UNU-WIDER), Helsink. Page 3. https://www.wider.unu.edu/sites/default/files/wp2010-82.pdf. Accessed on November 9, 2020.

13 Michael, K. Musgrave. and Sam, Wong. (2016). Towards a more nuanced theory of elite capture in development projects. the importance of context and theories of power. Journal of Sustainable Development, 9(3). http://www.ccsenet.org/journal/index.php/ jsd/article/view/57442. Accessed November 11, 2020.

14 Kia, Bariledum. and Vurasi, Serebe, S. (2013). Political elites and the challenges of national development: the nigeria experience. European Scientific Journal, November, 9(31) 164, ISSN: 1857-7881 (Print) e - ISSN 1857-7431. https://core.ac.uk/download/ pdf/236407296.pdf. Accessed on November 9, 2020.

15 International Finance Corporation. Strategic Community Investment A Good Practice Handbook for Companies Doing Business in Emerging Markets. Page 28. https://www.ifc.org/wps/wcm/connect/95c6b4b5-2097-4f47-9518-7a21b8516c1a/12014completeweb.pdf?MOD=AJPERES\&CACHEID=ROOTWORKSPACE-95c6b4b5-2097-4f47-9518-7a21b8516c1a-jkD15-5. Accessed on November 9, 2020. 
According to Freeman, a stakeholder is "any group or individual who can affect or is affected by the achievement of the organization's objectives." 16 The International Standard Organization (ISO) in its ISO 21500 project management guidance defined the stakeholder as "a person, group or organization that has interests in, or can affect, be affected by, or perceive itself to be affected by, any aspect of the project"17. Similarly, the International Finance Corporation (IFC) states that "stakeholders are persons or groups who are directly or indirectly affected by a project, as well as those who may have interests in a project and/or the ability to influence its outcome, either positively or negatively" ${ }^{18}$. The Department for International Development (DFID) defines a stakeholder as “... any individual, community, group or organization with an interest in the outcome of a program, either as a result of being affected by it positively or negatively, or by being able to influence the activity in a positive or negative way"19. Whilst the Inter-American Development Bank defined stakeholders as "individuals, groups, or institutions with a stake, or an interest, in the project that may be positively or negatively affected" or "they may have an interest in it and be in a position to influence its outcomes' ${ }^{20}$. Furthermore, Carroll stated that the term is used to 'describe a person or group with a stake, a claim or an interest in the operations and decisions of the firm" 21 . Based on these definitions, a stakeholder is a natural or juristic person or a group of persons capable of influencing the implementation of a project or programme or will be affected by it.

It is noteworthy that power, legitimacy, and influence are intrinsic to the stakeholder and the elite. The World Bank stated that the stakeholder can be national or political actors, for example, legislators and governors ${ }^{22}$. Similarly, the Asian Development Bank (ADB) stated that there is a spectrum of stakeholders, some of whom are the 'elected officials' ${ }^{23}$. Therefore, the political elites can be referred to as key stakeholders because they can affect the implementation of projects within their sphere of influence.

At this juncture, our focus shifts to those areas where these elites can exert their influence within the public procurement cycle in Nigeria. But before that, it is noteworthy to mention that "[i]n democracies citizens have delegated the provision of public services to public agencies which are controlled and governed by elected politicians [writer's emphasis]"24. Consequently, the critical role played by the elites in the procurement process can never be overemphasized; in the article, "Public Procurement Re-Examined"25, Thai described the essence of this role in the scope of the public procurement process-consisting of five core elements.

Figure 1 shows how they work together to ensure that public procurement is effectively and efficiently implemented, and its objectives successfully achieved.

6 R. Edward Freeman (2010). Strategic Management: A Stakeholder Approach. Cambridge University Press, Page 46.

17 International Organisation for Standardisation. (2012). ISO 21500:2012, Guidance on Project Management. Geneva: International Organisation for Standardisation.

18 International Finance Corporation, World Bank Group. Stakeholder Engagement: Good Practice Handbook for Companies Doing Business in Emerging Markets. Page 10. https://www.ifc.org/wps/wcm/connect/affbc005-2569-4e58-9962-280c483baa12/ IFC_StakeholderEngagement.pdf?MOD=AJPERES\&CVID=jkD13-p. Accessed on July 8, 2020.

19 Department for International Development. Tools for Development A handbook for those engaged in development activity (Tools for Development / Version 15.1 / March 2003), page 2.1. https://webarchive.nationalarchives.gov.uk/+/http:/www.dfid.gov.uk/ documents/publications/toolsfordevelopment.pdf. Accessed on July 9, 2020.

20 Kvam, Reidar. (2017). Meaningful stakeholder consultation. Inter-American Development Bank Series on Environmental and Social Risk and Opportunity, Page 7. https://publications.iadb.org/publications/english/document/Meaningful-StakeholderConsultation.pdf. Accessed on August 6, 2020.

${ }^{21}$ Archie, B. Caroll. (1991). The pyramid of corporate social responsibility: Towards the moral management of organizational stakeholder. Business Horizons, July-August, page 43. https://www.researchgate.net/publication/4883660_The_Pyramid_of_ Corporate_Social_Responsibility_Toward_the_Moral_Management_of_Organizational_Stakeholders. Accessed on August 15, 2020.

22 The World Bank Group. Anticorruption. Stakeholder Analysis. http://www1.worldbank.org/publicsector/anticorrupt/ PoliticalEconomy/stakeholderanalysis.htm. Accessed on August 18, 2020.

23 Jalal, Kazi, F. (1995). Mainstreaming participatory development processes. The Asian Development Bank, https://think-asia.org/ bitstream/handle/11540/4872/Mainstreaming\%20Participatory\%20Development\%20Processes.pdf? sequence $=1$. Accessed on November $18,2020$.

24 Vluggen, Rob; Gelderman, Cees J.; Semeijn, Janjaap; van Pelt, Marc. (2019). Sustainable public procurement-external forces and accountability. Sustainability, 11(20), 5696. Page 3. https://www.mdpi.com/2071-1050/11/20/5696. Accessed on November 14, 2020 .

25 Thai, K.V. (2001). Public procurement re-examined. Journal of Public Procure, 1(9-50), 17 and 18. http://ippa.org/jopp/ download/vol1/Thai.pdf. Accessed on November 14, 2020. 


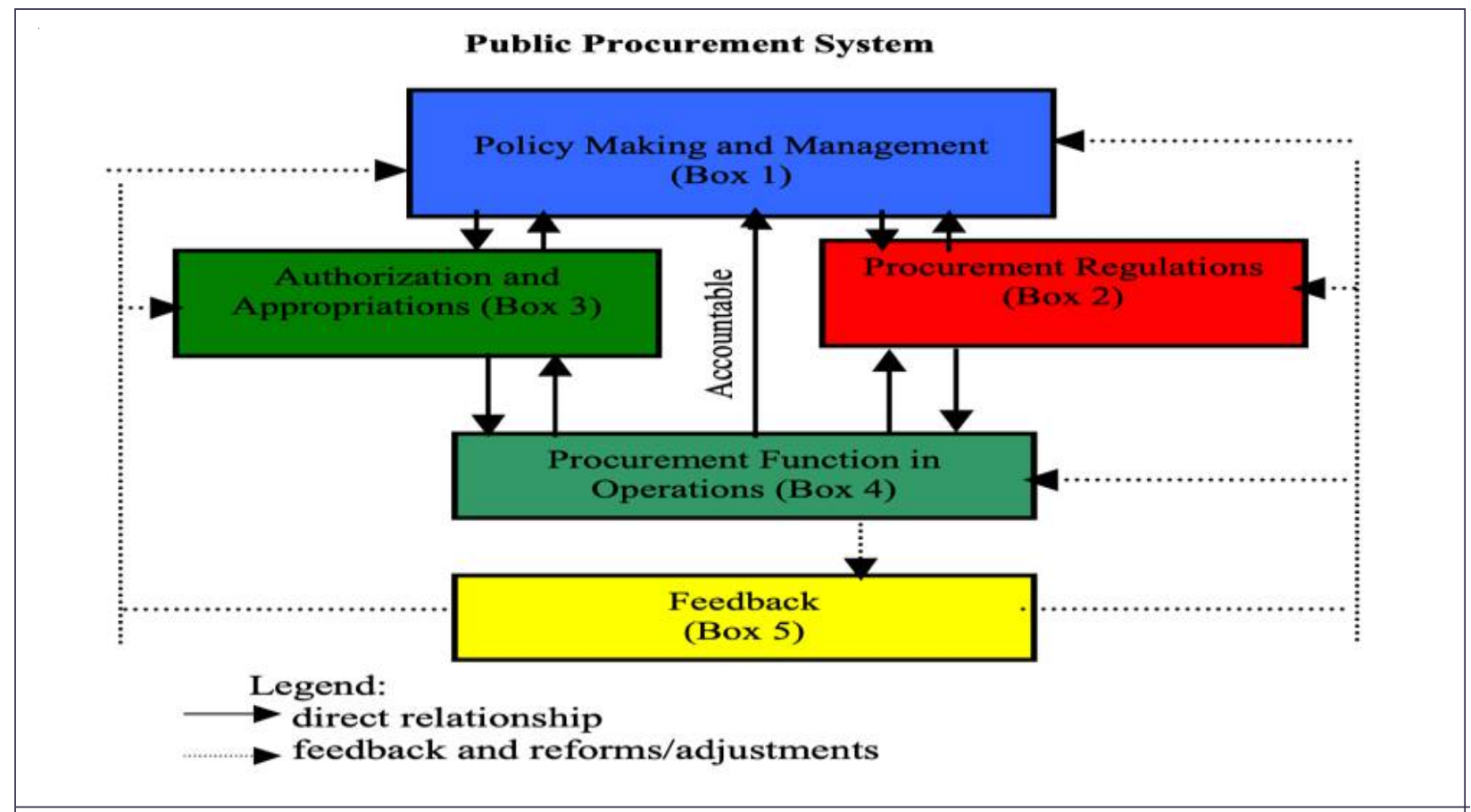

Figure 1: Public procurement system ${ }^{26}$

Source: Public Procurement Re-examined. Khi V. Thai (2001)

Figure 1 above, Thai illustrated the interrelationship and the critical roles played by the elites in the public procurement system in the course of carrying out their responsibilities. It will be noted that the legislative branch is responsible for the enactment of the public procurement law as well as the authorization and appropriation of funds and programs.

Figure 1: Box 3. The executive branch in operationalizing the public procurement law makes policies, regulations and manages the procurement process thereto, through the relevant agencies of government.

Figure 1: Box 1, 2 and 4. It is worth noting that the executive branch typically derives its authority from the laws enacted by the legislative branch. All of this makes clear the importance of engaging the elites who constitute a critical part of both branches of government.

The illustration above (Figure 1) applies to Nigeria. Given that the political elites are public officials who are either elected or appointed. Such as the president, governors, chairmen (mayors), legislators, and appointees; who make up the executive and legislative branches of government. Interestingly, part of their functions includes enacting laws, regulations and their implementation ${ }^{27}$ through the structure of government. These functions of the political elites are well defined in the Constitution of the Federal Republic of Nigeria $^{28}$ and other subsidiary legislation ${ }^{29}$. It may be argued that an elite may deliberately frustrate a public procurement process where his or her interest is not taken into consideration. This, however, depends on the prominence ${ }^{30}$ of such elite as a stakeholder; for example, the president or governor can stifle a public procurement process by refusing or delaying to perform his/her duties as spelt out in the law. In contrast, an appointee or nominee, in contrast, can frustrate the progress of a project by relying on the inherent inefficiency in the bureaucracy. Similarly, the elites in the legislative branch, if not adequately engaged, may stifle the enactment of enabling legislation or reform of an existing law needed to improve the process and systems, which might otherwise

26 Diagram by Prof Thai, K.V. (2001). Public procurement re-examined. Journal of Public Procure, 1,(9-50). http://ippa.org/jopp/ download/vol1/Thai.pdf. Accessed on November 14, 2020.

27 The Nigerian Scholars. Functions and powers of the executive, https://nigerianscholars.com/tutorials/arms-of-government/functionsand-powers-of-the-executive/. Accessed on October 26, 2020.

28 Constitution of the Federal Republic of Nigeria https://wipolex.wipo.int/en/text/179202. Accessed on November 17, 2020.

29 The Public Procurement Act, 2007. The Rivers State Public Procurement Law, No. 4, 2008.

30 Ricardo Corrêa Gomes. (2004). Who are the relevant stakeholders to the local government context? empirical evidences on environmental influences in the decision-making process of english local authorities. Brazilian Administrative Review, 1(1), 34-52, Jul./Dec. Page 37. https://bar.anpad.org.br/index.php/bar/article/view/9/4. Accessed on July 15, 2020. 
guarantee the success of future projects; even undue delay in the authorization and appropriation of funding for proposed or ongoing projects could become critical.

Although the elites (particularly the executive) are saddled with the responsibility of implementing projects, part of the constitutional ${ }^{31}$ duty of the legislature is to pass the appropriation bill (budget proposal) into law which grants the executive access to the public funds specified in the law. In addition, the legislative branch is empowered to carry out oversight functions to ensure that the public funds appropriated for these projects were used for their purposes and not diverted or misappropriated. Given the symbiotic relationship between the legislative and the executive branches of government and the cooperation that is expected to exist, the executive engages the legislature during the needs identification and analysis to gain the legislators' inputs and buy-in, whilst the legislature cooperates with the executive to pass the appropriation bill into law. In so doing, the legislature gives power to the executive to have access to public funds for the specified projects in the budget or appropriation law, thereby enabling the implementation of those projects. The nexus is that engaging the elites (in both the legislative and executive branches) creates the circumstances that will make the government actively participate and fulfill its obligations in the successful implementation of development projects, whether those projects are wholly financed with public funds or are co-financed with MDIs or a PPP. Therefore, it is an axiomatic fact that the critical role played by the elites in the public procurement systems makes engaging them a top priority if the implementation of the projects is to succeed. Though, certain interests of these elites may be antithetical to development and can often lead to elite capture. ${ }^{32}$

As mentioned earlier, political elites are elected to public offices through rigorous campaigns in which the electorate are often promised policies and programs that will stimulate economic growth, generate employment, drive reforms, and bring institutional and infrastructural development. Hence, a development-conscious elite would support and take advantage of projects co-financed with MDIs in order to demonstrate their desire to fulfill their campaign promises. Furthermore, these categories of elites, being connected to the grassroots, possess a better ability to communicate the objectives of projects and their advantages to the populace or those who are to be directly affected by the given projects. Oftentimes the mode of communication is informal so as to bypass bureaucracies, get beyond the demands of zealous individuals and organized groups, to engage with hear the perspectives and experiential knowledge of everyday people $^{33}$. In the article 'Political leaders and public engagement: the hidden world of informal elite-citizen interaction' ${ }^{34}$, Hendricks and Lees Marshment argued that "[p]oliticians are much more connected to the people than anyone [writer's emphasis] and that as everyone else lives in bubbles with regards to the connection with the people". Interestingly, to garner political mileage for subsequent elections, these elites ensure that they are visible, vocal and actively take part throughout the procurement cycle of public projects, providing inputs during conceptualization, monitoring the selection and award processes, and participating in contract execution either directly or through support to civil society organizations (CSO) (which lend effectiveness). The elites hope to be seen, heard, and recognized as playing a pivotal role in attracting as well as ensuring the completion of these projects. And such completed projects typically will be vaunted during the next electioneering campaign as part of the achievements of these elites. The elites' involvement also has real practical importance - in essence, the elites, when effectively engaged, can contribute towards the successful completion of the procurement process, as "elite involvement also has the potential to facilitate positive development outcomes and high levels of stakeholder satisfaction if appropriate checks are in place." ${ }^{35}$

31 Constitution of the Federal Republic of Nigeria. Chapter V, Part I. https://wipolex.wipo.int/en/text/179202. Accessed on November 17,2020

32 Sam, Wong. Elite Capture or Capture Elites? Lessons from the 'Counter-elite' and 'Co-opt-elite' Approaches in Bangladesh and Ghana. Page 3. Working Paper No. 2010/82, United Nations University World Institute for Development Economics Research https://www.wider.unu.edu/sites/default/files/wp2010-82.pdf. Accessed on November 9, 2020

33 Carolyn, M. Hendriks. and Jennifer, Lees-Marshment. (2018). Political leaders and public engagement: the hidden world of informal elite-citizen interaction. ID POST-10-17-0317 15 June. page 28. https://researchspace.auckland.ac.nz/bitstream/handle/ 2292/43583/full_Political_Studies_14June2018.pdf? sequence=14\&isAllowed=y . Accessed on October 27, 2020.

34 Carolyn, M. Hendriks. and Jennifer, Lees-Marshment. (2018). Political leaders and public engagement: the hidden world of informal elite-citizen interaction. ID POST-10-17-0317 15 June. page 29. https://researchspace.auckland.ac.nz/bitstream/handle/ 2292/43583/full_Political_Studies_14June2018.pdf?sequence=14\&isAllowed=y. Accessed on October 27, 2020.

35 The World Bank. (2008). CDD and elite capture: reframing the conversation. Social Development How to Series, 3. February Page 1. http://documents1. worldbank.org/curated/zh/397181468137726436/pdf/430830BRI001NO1ing0the0Conversation. pdf. Accessed on November 9, 2020 
It is worth mentioning that these development-oriented elites, who are also referred to as 'benevolent elites', ${ }^{36}$ may by their policies, programs, reforms and partnerships stimulate the right environment for Foreign Direct Investments (FDIs), which in turn boost economic growth. It is important to note that in addition to investment-friendly environment reforms ${ }^{37}$, policies and programs, there has been a direct and strong empirical linkage between the public procurement of infrastructures such as roads, energy, water, security, utilities, and the attraction of foreign investment ${ }^{38}$ into Rivers $^{2}$ State as well as more broadly in Nigeria. This link between infrastructure and economic growth arises because the provision of infrastructure by the government is a primary function of public procurement, hence, 'benevolent elites' who are motivated by the genuine desire to engender development will ensure that a sound public procurement system is established in order to guarantee transparency, integrity, competition and value for money. And as expected, the projects delivered through a sound public procurement process are always of remarkably high quality and standard. At this juncture, it is worth clarifying that the elites worth engaging are those who have been seen to make "deliberate decisions to achieve developmental vision and [have] developed the ability to manage conflict, devi[s]e strategies for cooperation, negotiation and compromises designed to avoid alienation and disgruntlement among significant sections of the key elites" 39 and stakeholders.

Having identified the elites' role in advancing the procurement of infrastructure, it is important to understand how elites influence each stage in the procurement process. Within the context of Nigeria, including Rivers State, it will appear that the level of influence exerted by elites varies according to the step in the public procurement process, that is, from the needs identification and analysis leading up to the award and implementation of the project, as illustrated in Figure 2.

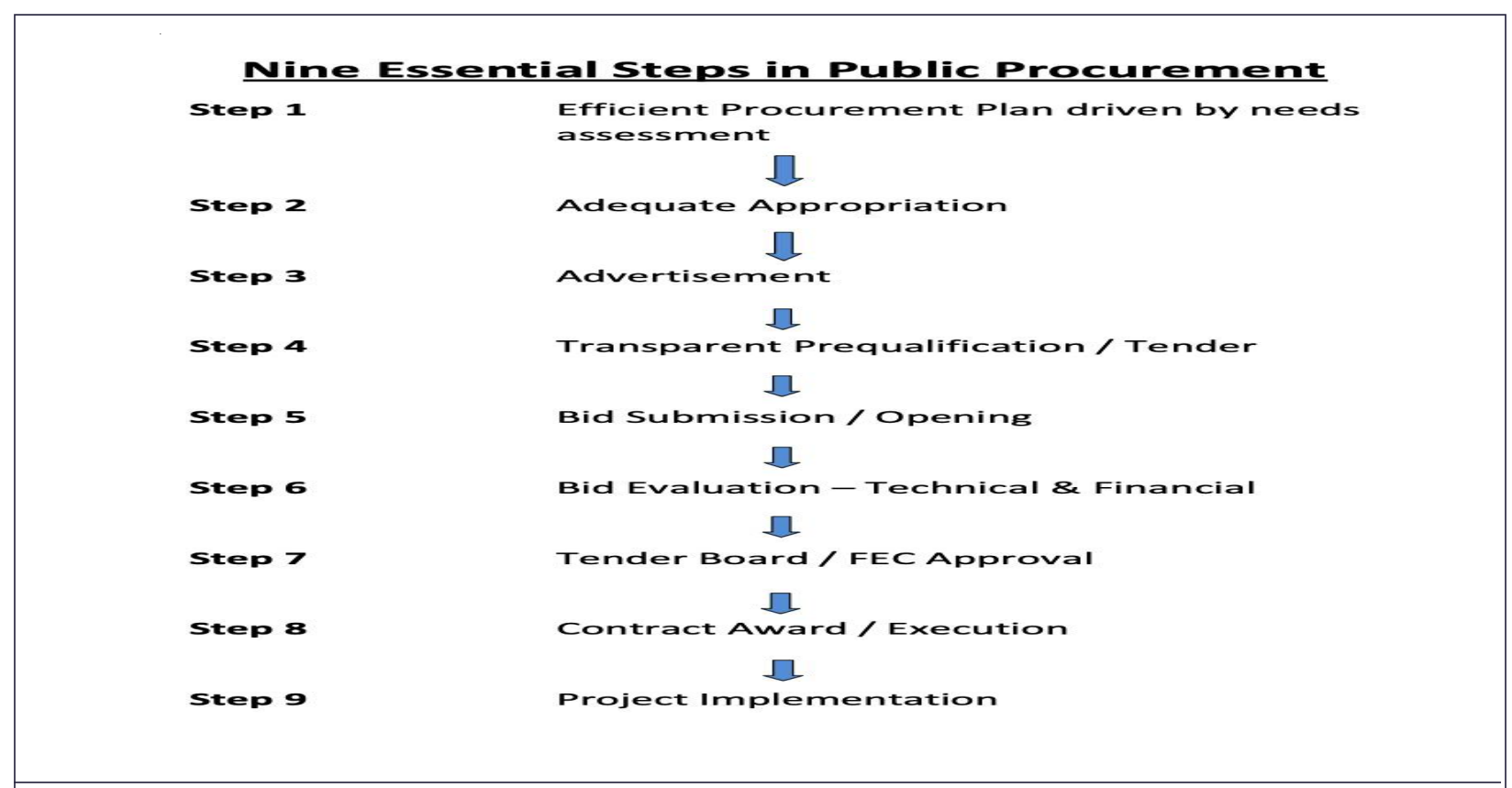

Figure 2: The nine essential steps in public procurement ${ }^{40}$

Source: The Bureau on Public Procurement, Abuja, Nigeria.

36 The World Bank. (2008). CDD and elite capture: reframing the conversation. Social Development How to Series, 3 . February Page 1. http://documents1.worldbank.org/curated/zh/397181468137726436/pdf/430830BRI001NO1ing0the0Conversation. pdf. Accessed on November 9, 2020.

37 Frank, Sader. Attracting foreign direct investment into infrastructure. why is it so difficult. The World Bank, Foreign Investment Advisory Service Occasional Paper 12. Page 98. http://documents1.worldbank.org/curated/en/628631468779704134/pdf/ 29744001821314602140Attracting0FDI.pdf. Accessed on October 29, 2020.

38 The Guardian, October 11, 2017. Kogi state in nigeria reforms public procurement process to attract foreign investment. https:// guardian.ng/business-services/kogi-reforms-public-procurement-process-to-attract-foreign-investment/ . Nordea. "Nigeria: Investing in Nigeria" https://www.nordeatrade.com/en/explore-new-market/nigeria/investment. Accessed on October 29, 2020.

39 David, Sebudubudu. and Patrick, Molutsi. (2011). The elite as a critical factor in national development: The case of Botswana. Discussion page 58, Nordiska Afrikainstitutet, Uppsala 2011. https://www.diva-portal.org/smash/get/diva2:451270/ FULLTEXT01.pdf. Accessed on November 30, 2020.

40 Bureau of Public Procurement. Nine Essential Steps in Public Procurement. https://www.bpp.gov.ng/wp-content/uploads/2019/01/ Nine-Essential-Steps-in-Public-Procurement.pdf. Accessed on November 10, 2020. 
For clarity, it is important to identify those steps in the procurement process in which the elites are actively involved and to explain how critical their roles are in those steps; thus:

Step 1 - Efficient procurement plan driven by needs assessment: During this step, the elites are consulted during the needs identification and assessment to identify projects that will be captured in the procurement plan. The elites' input will be reflected in the initial project proposed and captured in the budget or appropriation bill.

Step 2 - Adequate appropriation: In Nigeria, the political elites in the executive and legislature are responsible for passing appropriations bills into law and approving the release of funds for the respective projects. The legislature passes the appropriation bill into law, whilst officials in the executive branch approve the release of these appropriated funds for the respective projects.

The elites typically are not heavily involved in the next, technical steps in the procurement, which include advertisement, prequalification, bid submission and bid evaluation.

Step 7 - Tender Board/FEC approval: The award of procurement contracts above certain thresholds ${ }^{41}$ requires the approval of the Federal Executive Council (FEC) ${ }^{42}$. The FEC is constituted by the president and ministers, including the head of the public service of Nigeria, who are all political elites (except the head of the public service); besides the president and vice president, all the other members of the FEC are appointed by the president. Similarly, in the states, a parallel body is referred to as the State Executive Council (SEC). It is constituted by the governor, deputy governor and commissioners. Besides the governor and the deputy governor, all other members are appointed by the governor. In Rivers State, the Director-General of the Rivers State Bureau on Public Procurement (RSBoPP) is also a member of the $\mathrm{SEC}^{43}$

Step 8 - Contract award/Execution: The relevant elites are actively involved during this step, for they ensure that appropriated and approved funds are released on time for contract implementation. Also, it is during this step that cofinancing and counterpart funding are implemented, which means that the government will be expected to fulfill its financial obligations within the terms and conditions of the procurement and project. The action or inaction of these elites may stifle or truncate the procurement process if they fail to perform their duties to implement the government's obligations, or if they deliberately frustrate the process by inordinately delaying performing their responsibilities, which include implementing the government's financial obligation in the cofinancing or counterpart funding arrangement for the projects. In this regard, it is worth noting that approvals for contract award and project implementation are obtained through the $\mathrm{FEC}^{44}$ and SEC.

Step 9 - Project implementation: At the project implementation stage, the elites play critical roles in ensuring that the contractor is given all the necessary support for the implementation of the project, such as by engaging the primary stakeholders that will be directly affected by the project. The elites can help ensure that the stakeholders understand the objectives and benefits derivable from the projects. The elites' advocacy can be implemented through active outreach through electronic and print media and can include face-to-face meetings. Oftentimes these elites are the elected representatives of the primary stakeholders, and so they can sway these primary stakeholders to support and cooperate with the contractors during the implementation of the projects. For example, primary stakeholders can be persuaded to relocate from their ancestral lands to make room for infrastructural development, after their elected representatives engage them. The primary stakeholders can also ensure the safety and security of the contractor's staff and equipment during project implementation; this is very common in Nigeria, particularly in areas prone to youth restiveness ${ }^{45}$.

41 Bureau of Public Procurement 'Approval Threshold'. https://www.bpp.gov.ng/wp-content/uploads/2019/02/ Approved_Revised_Thresholds_for_Service-Wide_Application-updated.pdf. Accessed on November 10, 2020. It is worth mentioning that the Federal Executive Council (FEC) is required to approve the procurement of goods valued at 100 Million Naira and above, works valued at 500 Million Naira and above, and services 100 Million Naira and above, whilst, special works (Nigerian National Petroleum Corporation) valued at 2.7Billion Naira (US\$20 Million) and above. All of which are in contravention of the Public Procurement Act, 2007 (PPA), as neither the PPA nor the Public Procurement Regulations for Goods and Works, and Consultancy Services provided for the duties being performed by the FEC. This aberration has been left uncorrected by successive government since the enactment of the PPA in 2007.

42 Embassy of the Federal Republic of Nigeria, Washington D.C., Members of the Federal Executive Council. http:// www.nigeriaembassyusa.org/index.php?page=federal-executive-council. Accessed on November 10, 2020.

43 Government of Rivers State of Nigeria. The Executive, https://www.riversstate.gov.ng/executive. Accessed on November 10, 2020.

44 The Guardian, May 13, 2018. Public Procurement Council to be Inaugurated. Opinion by Martin Oloja. https://guardian.ng/ opinion/public-procurement-council-to-be-inaugurated/. Accessed on November 10, 2020

45 Anasi, Stella N.I. (2010). Curbing youth restiveness in nigeria:the role of information and libraries. Library Philosophy and Practice (e-journal), 388. https://digitalcommons.unl.edu/libphilprac/388. Accessed on November 11, 2020. 
Furthermore, these elites perform an oversight function by monitoring implementation to ensure that the project will be delivered as scheduled.

As was discussed above, the Nigerian elites play crucial roles in many of the steps of the procurement cycle illustrated in (Figure 2). It has been suggested that adequately engaging the elites is likely to effectively promote wider participation of the people in the process, thus, creating momentum, instilling a sense of ownership, and increasing public satisfaction in procurement outcomes ${ }^{46}$. Furthermore, the elites' involvement may not necessarily have a negative impact if a robust system of accountability_legal, political, and professional ${ }^{47}$ is put in place to protect against elite capture and abuse of official privileges. Conversely, though, these political elites if not adequately engaged may withdraw their support or commitment, which can cause undue delay in the project or even cancellation owing to lack of performance, which in turn can result in the abandonment of the project.

\subsection{Reasons elites abandon projects}

An abandoned project can be described as "the refusal or failure . . . to complete a contract before . . . practical completion dates" ${ }^{48}$ because of one or several reasons. Ihuah and Benibo (citing Spelman) posited that it "is the act of discontinuing any activities or maintenance works on such development project within a time frame of the contract

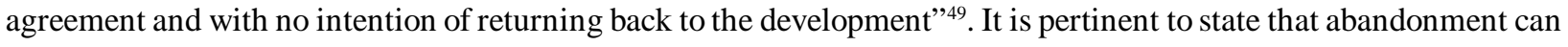
occur at any stage in the procurement or project life cycle.

Several researchers have suggested that engaged elites often hijack or capture projects for personal gains, and where this is not possible (or is no longer possible) they are likely to withdraw their support and renege on earlier commitments to see the projects through to completion. And depending on the elites" stakeholder "salience" 50 - a measure of the elite individual's power and legitimacy, the project may be unduly delayed, smothered by government bureaucracy, which is inherently inefficient or, at worst, a complete roadblock. For example, in Nigeria, the president and governor have power (control of public resources) and legitimacy (bestowed by the constitution) as such are key stakeholders with a high salience. Therefore, their withdrawal of support or reneging on commitments to a public project would lead to an abandonment of the project. While, under similar circumstances, an appointee's or nominee's obstruction or intransigence, masked by a broader bureaucracy, may result in undue and costly delays that lead to schedule overrun $^{51}$. Also, a prolonged delay may be exacerbated by the country's persistent inflation, with the resultant outcome being cost and schedule overruns with collateral negative impacts on the citizenry.

Similarly, numerous studies suggest that policy shifts ${ }^{52}$ frequently cause elites to abandon projects and that this unfortunate situation is the corollary of a change in government, particularly when an opposition party takes power. Any new government typically will have its agenda and priorities and therefore will divert appropriated funds to other ends. Studies have also shown that the elites in the succeeding government tend not to show interest in projects initiated by a previous government; this indifference is tactical, so that their predecessors do not gain political or electoral strength from the completion of their own sponsored projects, and because there may be little (if anything) left

46 The World Bank. (2008). CDD and elite capture: reframing the conversation. Social Development How to Series, 3. February Page 1. http://documents1.worldbank.org/curated/zh/397181468137726436/pdf/430830BRI001NO1ing0the0Conversation. pdf. Accessed on November 9, 2020.

47 Vluggen, Rob., Gelderman, Cees J., Semeijn, Janjaap. and van Pelt, Marc. (2019). Sustainable public procurement—external forces and accountability. Sustainability. 11(20). 5696. Page 5. https://www.mdpi.com/2071-1050/11/20/5696. Accessed on November 14, 2020.

48 E.C. Ubani and C.N. Ononuju. A study of failure and abandonment of public sector-driven civil engineering projects in Nigeria: An empirical review. Available from https://www.researchgate.net/publication/273009510_A_study_of_failure_and_abandonment _of_public_sector-driven_civil_engineering_projects_in_Nigeria_An_empirical_review. Accessed on November 17, 2020.

49 Ihuah, Paulinus Woka1 and Benebo, Abiye Miebaka. Page 25, https://www.researchgate.net/publication/265793952_An_assessment_ of_the_causes_and_effects_of_abandonment_of_development_projects_on_real_property_values_in_Nigeria. Accessed on November 19, 2020.

50 Ronald K. Mitchell, Bradley R. Agle and Donna J. Wood. (1997). Toward a theory of stakeholder identification and salience: defining the principle of who and what really counts. The Academy of Management Review, October, 22(4) 853-886. http:// www.jstor.com/stable/259247. Accessed on September 27, 2020.

51 Dumo Mac-Barango. Construction Project Abandonment: An Appraisal of Causes, Effects and Remedies. Page 3. https://iiardpub.org/ get/WJIMT/VOL\%201/CONSTRUCTION\%20PROJECT.pdf. Accessed 16 November 2020.

52 Nnamdi Nweze. "Failure of Public Infrastructure Projects in Nigeria: Causes, Effects and Solutions." Page 3. Texila International Journal of Management Volume 2, Issue 2, Dec 2016. https://www.texilajournal.com/management/article/566-failure-of-publi Accessed 15 November 2020. 
to plunder financially from such projects. In Nigeria, corruption has become institutionalized, glamorized ${ }^{53}$ and a central part of social and political interaction — and a corrupt realm, ironically, where religion, ethnicity and status are largely irrelevant. It is quite puzzling to observe that these elites are tacitly encouraged to loot, and yet are sometimes openly defended based on ethnicity and religion by some of the very people impoverished by the elites' rank corruption. Therefore, it may be suggested that corruption could be a strong motivation for elites to abandon projects, particularly for those projects funded or co-financed by the multilateral development institutions, projects in which the procurement or project life cycle are governed by the rules and regulations of the MDIs. These disconnect between project timelines and electoral cycles or corruption opportunities may help explain elites' apathetic commitment to certain projects. As a result, wholly funded public projects may be abandoned if the affected elites believe that the project's potential reputational gains or corrupt payments have been fully drained away by officials in a prior government and that the project is no longer a useful wellspring of selfish opportunity.

\subsection{Engaging the elites as stakeholders}

It has been recognized that key stakeholders are critical to the success or failure of an organization or project; this explains the rapid growth in critical analyses of stakeholders' roles. ${ }^{54}$ Although stakeholders have been the subject of robust discussions in academia and the business community, there is relatively little literature on the role of stakeholders in procuring public projects. In their work on 'Incrementalism: Eroding the Impediments to a Global Procurement Markets', Yukins and Schooner stated that the "fundamental issue of identifying and understanding the interests and priorities of the various stakeholders in public procurement - is a critical yet underexplored piece of the public procurement policy puzzle" 55 . This gap in the literature is particularly acute when it comes to studies focused on the engagement of elites in public procurement.

The World Bank, recognizing the vital role that elites can play in the implementation of projects, has categorized them as stakeholders (as national and political actors), ${ }^{56}$ in essence acknowledging the leading role elites play in development ${ }^{57}$. Likewise, researchers "argue that the political settlement is central to all development; and one that does not exclude powerful players is more likely to prevent [writer's emphasis] conflict" 58 , or deliberate sabotage of development. Furthermore, as studies suggest that power is the most critical dimension of any relationship with stakeholders, the utmost care and monitoring are necessary when dealing with stakeholders who hold the greatest power, which very often are the elites ${ }^{59}$. In sum, it is clear that engaging elites is paramount to success in cultures like Nigeria, and having a strategy for engagement is crucial. While the MDIs may have robust stakeholder engagement strategies, what is missing is the dedicated implementation and monitoring to achieve the desired objectives.

It is worthy of mention that "stakeholder engagement is an inexpensive and efficient way of creating a better operational environment for a project. The consultation process reduces risks and increases its chance of success" 60 . Stakeholder engagement focuses on ensuring that the interactive and non-interactive forms of engagement ${ }^{61}$ between

53 Adeola, G.T. (2008). Military Legacies and the Challenge of Managing Diversities in Nigeria's Federation. A Paper Presented to the 20th Summer University Programme of the Institute of Federalism, Fribourg, Switzerland.

54 Archie. B. Caroll and Juha Nasi. (1997). "Understanding Stakeholder Thinking: Themes from a Finnish Conference" Business Ethics 6 (1):46-51, page 46. https://www.academia.edu/860778/Understanding_Stakeholder_Thinking_Themes_From_a_Finnish_ Conference. Accessed on 28 August 2020

55 Christopher R. Yukins and Steven L. Schooner (2007). "Incrementalism: Eroding the Impediments to a Global Public Procurement Market” 38 GEO. J. INT'L L. 529, page 565. https://scholarship.law.gwu.edu/cgi/viewcontent.cgi?article=1119\& context=faculty_publications> accessed on 28 August 2020.

56 The World Bank Group. "Anticorruption. Stakeholder Analysis." http://www1.worldbank.org/publicsector/anticorrupt/ PoliticalEconomy/stakeholderanalysis.htm. Accessed on 18 August, 2020.

57 The World Bank (2008). “CDD and Elite Capture: Reframing the Conversation." Social Development How to Series. Vol. 3. February Page 1. http://documents1.worldbank.org/curated/zh/397181468137726436/pdf/430830BRI001 NO1 ing0the0 Conversation. pdf<accessed 9 November 2020

58 Department for International Development. (2001-2010) The Politics of Poverty: Elites, Citizens and States A Synthesis Paper Findings from ten years of DFID-funded research on Governance and Fragile States. page 8. https://www.oecd.org/derec/unitedkingdom/ 48688822.pdf. Accessed on 9 November 2020

59 Emerson Wagner Mainardes, Helena Alves \& Mario Raposo 'Stakeholder theory: issues to resolve'. https://www.researchgate.net/ publication/243460719_Stakeholder_theory_Issues_to_resolve > page 236. Accessed on 18 August 2020.

60 PPP Knowledge Lab 'Stakeholder Communication and Engagement'. https://pppknowledgelab.org/guide/sections/39-stakeholdercommunication-and-engagement. Accessed 10 July 2020.

61 Rosaria Di Nucci and Michael Krug FUB F.F. (2018). "Stakeholder Engagement and Consultation Plans for all WinWind Countries." Deliverables 3.2. Ref. Ares (2018)1738516 - 29/03/2018, 29 March 2018. Page 9. https://ec.europa.eu/research/participants/ documents/downloadPublic?documentIds=080166e5b99dbb24\&appId=PPGMS<15 August 2020. 
all actors (lead and minor) in the project are effectively and efficiently managed to achieve the successful completion of the project ${ }^{62}$. In the Government of Western Australia's guide to stakeholder engagement, "Planning Partnership Guide: Undertaking Co-Design under the Delivering Community Services in Partnership Policy" ${ }^{63}$, stakeholder engagement is referred to as "a planned process of working with identified stakeholders to achieve the defined purpose". It has become a general practice that engaging stakeholders is obligatory in projects' implementation and the only optional aspect is the 'decision of when and how to successfully carry out the engagement ${ }^{64}$. According to the AA1000 Stakeholder Engagement Standard, "a [s]uccessful engagement depends on understanding why an organization is engaging (the purpose), what issues to engage on (the scope), and who needs to be involved in the engagement (ownership, mandate, stakeholders)" ${ }^{65}$ Reasonably, "stakeholder engagement should be managed as one would manage any other business function - with clearly defined objectives and targets, professional, dedicated staff, established timelines and budget, and senior management responsibility and oversight" 66 .

Considering that stakeholder engagement is a two-way process ${ }^{67}$, the communications should be robust and transparent, with the frequency and details of communication turning on how critical—how "salient"-the involved elites are. For example, in Nigeria, the president and the governor are the elites with the highest salience, and as such information exchange with them should be frequent and must not be asymmetric. Communications are particularly important, at the conceptualization, selection and award stages of a project, because powerful stakeholders' engagement very it determines whether the project will gain strong support—or languish. The president or governor or their representative (who, if he lacks the requisite capacity, must be buttressed by a consultant who represents the government) must be sufficiently advised at the outset of each stage (conceptualization, selection and award) as to the principles guiding the process and on why any deviation may be counterproductive. These communications must be supported by "research, analysis [particularly cost-benefit analysis] and opinions" ${ }^{68}$ premised on similar circumstances to lend the credibility of the communication. Studies show that these high-level communications should be assigned to a senior member of the management staff ${ }^{69}$, who can take decisions that will adapt to evolving circumstances as the interface progress with the president and the governor (or their representative). Furthermore, project committees should be constituted on a case-by-case basis, made up of representatives of all stakeholders for periodic consultations. ${ }^{70}$ To ensure the success of these project committees, the MDIs can identify and select 'believers' ${ }^{71}$ (persons who believe in

62 R. Edward Freeman, Jeffrey Harrison, Andrew Wicks, Bidhan Parmar, Simone De Colle, and Lauren Purnell (2010). "Stakeholder Theory: The State of the Art." Cambridge, U.K.: Cambridge University Press, 2010. https://www.academia.edu/35325231/Stakeholder_ Theory_The_State_of_the_Art. Accessed on 28 August 2020

63 Government of Western Australia, Government Procurement "Planning in Partnership Guide: Undertaking Co-Design under the Delivering Community Services in Partnership Policy.” Page 5. 1st Edition - October 2018. https://www.wa.gov.au/sites/default/ files/2019-08/Community\%20Services\%20Procurement\%20-\%20Planning\%20in\%20Partnership\%20Guide.pdf . Accessed on 14 November 2020.

64 Neil Jeffery Doughty Centre, Cranfield School of Management:Stakeholder Engagement: A Road Map to Meaningful Engagement -July 2009, page 8 < https://dspace.lib.cranfield.ac.uk/bitstream/handle/1826/3801/Stakeholder_engagement-2009.pdf?sequence $=3 \&$ isAllowed $=\mathrm{y}$. Accessed on 20 August 2020 .

65 AA1000 Stakeholder Engagement Standard (SES) 2015, AccountAbility Publication. Page 15. https://www.accountability.org/ static/940dc017198458fed647f73ad5d47a95/aa1000ses_2015.pdf. Accessed 14 November 2020.

66 International Finance Corporation, World Bank Group. Stakeholder Engagement: Good Practice Handbook for Companies Doing Business in Emerging Markets. Page 100. https://www.ifc.org/wps/wcm/connect/affbc005-2569-4e58-9962-280c483baa12/IFC_ StakeholderEngagement.pdf?MOD=AJPERES\&CVID=jkD13-p. Accessed on 8 July 2020.

67 AA1000 Stakeholder Engagement Standard (SES) 2015, AccountAbility Publication, Page 21. https://www.accountability.org/ static/940dc017198458fed647f73ad5d47a95/aa1000ses_2015.pdf. Accessed 14 November 2020.

68 Neil Jeffery Doughty Centre, Cranfield School of Management: Stakeholder Engagement: A Road Map to Meaningful Engagement -July 2009, page 27. https://dspace.lib.cranfield.ac.uk/bitstream/handle/1826/3801/Stakeholder_engagement-2009.pdf? sequence $=3 \&$ isAllowed $=\mathrm{y}<$ accessed on 20 August 2020 .

69 International Finance Corporation, World Bank Group. Stakeholder Engagement: Good Practice Handbook for Companies Doing Business in Emerging Markets. Page 100. https://www.ifc.org/wps/wcm/connect/affbc005-2569-4e58-9962-280c483baa12/ IFC_StakeholderEngagement.pdf?MOD=AJPERES\&CVID=jkD13-p. Accessed on 8 July 2020.

70 Neil Jeffery Doughty Centre, Cranfield School of Management:Stakeholder Engagement: A Road Map to Meaningful Engagement -July 2009, page 8. https://dspace.lib.cranfield.ac.uk/bitstream/handle/1826/3801/Stakeholder_engagement-2009.pdf?sequence= 3\&isAllowed=y. Accessed on 20 August 2020.

71 Eleni Panopoulou, Efthimios Tambouris, Konstantinos Tarabanis (CERTH): Stakeholder Community for Once-Only Principle: Reducing Administrative Burden for Citizens "Strategic stakeholder engagement plan (D2.2)". Version 1.4. (25 May 2019). Ref. Ares (2019)3552739 - 02/06/2019 Page 67. https://ec.europa.eu/research/participants/documents/downloadPublic?documentIds =080166e5c48ab206\&appId=PPGMS. Accessed 1 September 2020. 
and want the project to succeed) "to act as champion[s] or ambassadors inspiring and motivating others to get activated as well" ${ }^{72}$ These project proponents may also help to bridge the capacity gaps ${ }^{73}$, as in their engagement every stakeholder can contribute through the relevant committee, either by actively participating or by observing the procurement or project life cycle. The committee should meet periodically, depending on the nature and value of the project, and elites should be encouraged to appoint liaisons who can be contacted to give or get information pending project committee meetings.

As mentioned previously, the elites' self-interested responses to available project funds sharply increase the risks of project abandonment. The involved elites either may give weak support to a project if it appears that the funds allocated to the project have already been plundered, or-where a funded project stands available may engage vigorously to capture the project funds. Whilst it is a good initiative to engage the elites through participatory development ${ }^{74}$, it is important to 'balance it with good governance imperatives, such as ensuring an efficient management of public resources ${ }^{75}$-in other words, protective governance measures should check the elites' self-interest. As a precautionary measure, it is suggested that for projects under co-financing arrangement and public-private partnerships (PPPs), the counterpart funds from the state should be paid to or for that component directly from the federation account-this is an account into which revenues held by the government of Nigeria are remitted and shared between the states and the federal government. In this regard, it is noteworthy to mention that in Nigeria all negotiations and agreements for foreign loans and grants are carried out by the federal government on behalf of the states, and it is the federal government that receives the loan or grant, then disburses to the applying state. The states are allowed to administer the loan or grant for the purpose for which it was borrowed without the federal government monitoring the process, however, the repayment for the loan is deducted from the federation account by the federal government. This practice is quite puzzling and antithetical as cases of misappropriation and diversion of loans and grants abound in Nigeria. Particularly worrisome are projects under co-financing arrangement, where states have financial obligations to the projects; experience shows that states often renege on fulfilling these obligations. Therefore, it is suggested that the federal government (being the borrower) should be actively involved in the administration of the loan as well as disbursement of the counterpart funds directly from the federation account. Another advantage of this approach would be that that shifts in government or policies would have little or no impact on the progress of projects, as the federal government's oversight and funding would help shield the projects from the ambitions of self-interested (and rotating) elites. At the same time, the elites' positive engagement in projects should be reinforced by providing them with incentives (public recognition, for example, of positive project outcomes) to serve the needs of the citizenry ${ }^{76}$. Having put these measures in place, it is suggested the "consultation should be ongoing and iterative throughout the project cycle" 77 from conceptualisation through to decommissioning ${ }^{78}$, to ensure that the elites' genuine (and appropriate) concerns are identified and managed as project objectives. ${ }^{79}$

72 Eleni Panopoulou, Efthimios Tambouris, Konstantinos Tarabanis (2019). (CERTH): Stakeholder Community for Once-Only Principle: Reducing Administrative Burden for Citizens "Strategic stakeholder engagement plan (D2.2)". Version 1.4. (25 May 2019). Ref. Ares (2019)3552739 - 02/06/2019 Page 67. https://ec.europa.eu/research/participants/documents/ downloadPublic? documentIds=080166e5c48ab206\&appId=PPGMS. Accessed 1 September 2020.

73 AA1000 Stakeholder Engagement Standard (SES) (2015). AccountAbility Publication, 2015, page 15. https://www.accountability.org/ static/940dc017198458fed647f73ad5d47a95/aa1000ses_2015.pdf. Accessed 14 November 2020.

74 Jalal, Kazi F. (1995). "Mainstreaming Participatory Development Processes." The Asian Development Bank, 1995. It was defined as "Participatory development is a process through which stakeholders can influence and share control over development initiatives, and over the decisions and resources that affect themselves." https://think-asia.org/bitstream/handle/11540/4872/ Mainstreaming\%20Participatory\%20Development\%20Processes.pdf? sequence=1. Accessed 18 November 2020.

75 Schooner, Steven L, Gordon, Daniel I. and Wherry, Jessica L. (2008). "Public Procurement Systems: Unpacking Stakeholder Aspirations and Expectations" George Washington University Law School Public Law Research Paper No. 1133234; GWU Legal Studies Research Paper No. 1133234 (May 8, 2008). http://dx.doi.org/10.2139/ssrn.1133234. Accessed on20 June 2020.

76 The World Bank. "CDD and Elite Capture: Reframing the Conversation." Social Development How to Series. Vol. 3. February 2008 Page 1. http://documents1.worldbank.org/curated/zh/397181468137726436/pdf/430830BRI001 NO1 ing0the0Conversation. pdf. Accessed 9 November 2020

77 Kvam, Reidar. "Meaningful Stakeholder Consultation” Inter-American Development Bank Series on Environmental and Social Risk and Opportunity (2017). Page 8. https://publications.iadb.org/publications/english/document/Meaningful-StakeholderConsultation.pdf. Accessed on 6 August 2020.

78 Inter-American Development Bank 'Guidelines on Consultation and Stakeholder Engagement in IDB Projects. Environmental Safeguards Units (VPS/ESG) July 2013', https://publications.iadb.org/publications/english/document/Guidelines-on-Consultationand-Stakeholder-Engagement-in-IDB-Projects.pdf. < accessed on 8 August 2020> Page 18.

79 The Project Management Institute "A Guide to the Project Management Body of Knowledge”, Sixth Edition 2017. Page 505. 


\section{Stakeholder engagement in failed and abandoned projects in Nigeria}

As outlined in the conceptual models mentioned above, it can be deduced that projects have failed and been abandoned on a massive scale in Nigeria (including in Rivers State) due to any number of reasons. It was reported in a recent survey carried out by the Chartered Institute of Project Management of Nigeria (CIPMN) that the value of projects commenced but abandoned is over N12 tn Naira (\$30 bn at current exchange rates $)^{80}$. These abandoned and unduly delayed projects litter the landscape of the country, so much so that Osemenan, cited in 'Evaluation of Failures in Public Project Management Practices in Minna, Nigeria' ${ }^{81}$ referred to Nigeria as the "world's junk-yard of abandoned and failed projects"-a situation compounded by the continuous award of contracts for new projects which suffer similar fates ${ }^{82}$. Amongst the reasons identified for this appalling state of affairs are inadequate stakeholder engagement, pervasive corruption that permeates every stratum of society and a lack of technical capacity.

\subsection{Inadequacy of stakeholder engagement and management}

Numerous studies done by scholars and experiential knowledge shared by public practitioners support the fact that the absence or inadequate stakeholder engagement and management can stall or stop a project at any point in its life cycle ${ }^{83}$. Indeed, to emphasise the importance of involving the stakeholder, a stakeholder engagement plan (SEP) which details the strategy to engage the stakeholder and management is a compulsory requirement when soliciting for loans and grants from most of the MDIs ${ }^{84}$. Stakeholder management is the overarching strategy that calls for matching the objectives of the various project stakeholders with the objectives of the project, to ensure a win-win outcome ${ }^{85}$. Gomes (citing Mitchell et al.) stated that the stakeholder management process involves organizations "identify[ing] and assess[ing] their stakeholders as well as their salience (measurement of power and influence) in order to devise proper strategies for dealing with them" $"$. On the other hand, "stakeholder engagement can be defined as a process of involving and aligning the stakeholders to the project objectives and reducing the risks to achieve the project goal" ${ }^{87}$.

It is clear from the discussion above that a project can be abandoned because of community opposition-because of interference and disruption by the community, sometimes when there have not been sufficient, broad consultations to engage the community, including the local elites. The community's interference and disruption are often based on concerns that the project will displace people from their homes or farmlands or destroy cultural heritage, or otherwise cause adverse environmental impacts. In Nigeria, including in Rivers State, there have been many cases of contractors abandoning projects because of protracted community resistance ${ }^{88}$. Often the local elites are engaged to intervene and

80 The Africa Exponent, 29 (May 2019). "Nigeria's Sad Tale of Abandoned Projects Worth Over 12 Trillion". https:// www.africanexponent.com/post/10174-nigeria-and-the-curse-of-abandoned-uncompleted-projects. Accessed on 20 November 2020.

81 Akande, O.K, Olagunju, R.E, Obiora, O.C, Nsofor, C, Edem-Nse Y.G, Lawal, A.Iyisa, D, Kolo, W. (2018). "Evaluation of Failures in Public Projects Management Practices in Minna, Nigeria” Journal of Architecture and Construction Volume 1, Issue 3, 2018, pp. 15-24. Page 16 https://www.sryahwapublications.com/journal-of-architecture-and-construction/pdf/v1-i3/2.pdf < accessed 18 November 2020.

82 Adedamola Olabisi. "Causes, Effect and Solution to Abandonment of Building Projects in Osun State, Nigeria." Page 3. https:// www.academia.edu/37208573/causes_effect_and_solution_to_abandonment_of_building_projects_in_osun_state_nigeria. Accessed on 18 November 2020

83 KPMG. "Stakeholder management and communication" Project Advisory, Leadership Series 3. https://silo.tips/download/stakeholdermanagement-and-communication-project-advisory-leadership-series-3\#: :text=Stakeholder\%20 management \% 20 and $\%$ 20communication\%20is,perception\%20 of\%20a\%20projects\%20utility. < accessed on 21 November 2020.

84 The World Bank. "Procurement Guidance: Project Procurement Strategy for Development. Long Form Detailed Guidance July 2016." Published July 2016 - First Edition. Page 32 - 35, 93. http://pubdocs.worldbank.org/en/847531467334322069/PPSDLong-Form.pdf. Accessed on 20 June 2020.

85 Archie B Caroll. "The Pyramid of Corporate Social Responsibility: Towards the Moral Management of Organizational Stakeholder." Business Horizons/July-August 1991, page 43. https://www.researchgate.net/publication/4883660_The_Pyramid_of_Corporate_ Social_Responsibility_Toward_the_Moral_Management_of_Organizational_Stakeholders. Accessed 15 August 2020.

86 Ricardo Corrêa Gomes. Who are the relevant stakeholders to the local government context? Empirical evidences on environmental influences in the decision-making process of English local authorities. Page 37. https://bar.anpad.org.br/index.php/bar/article/view/ 9/4. Accessed on 15 July 2020.

87 Anil Barik. "Back to Basics: How to Make Stakeholder Engagement Meaningful” Journal of the Management of Training Institute, SAIL, Ranchi, Vol. 42 No1, April - June 2014, 2014. https://www.researchgate.net/publication/322086078_Back_to_Basics_How_to_ Make_Stakeholder_Engagement_Meaningful, Researchgate June, 2014 Page 10 < accessed 16 August 2020.

88 Ihuah, Paulinus Woka1 \& Benebo, Abiye Miebaka. "An Assessment of the causes and effects of abandonment of development projects on real property values in Nigeria”. Page 28. https://www.researchgate.net/publication/265793952_An_assessment _of_the_causes_and_effects_of_abandonment_of_development_projects_on_real_property_values_in_Nigeria. Accessed on 19 November 2020. 
to enlist community participation and support for a project. Actively involving the elites to resolve the contentions are usually successful. This is possible because these elites understood the cultural, political, and socioeconomic dynamics of the people ${ }^{89}$, as they were part of the affected communities ${ }^{90}$. It is interesting to note that the canny ability of the elites to communicate and dissuade the communities from causing disruptions and interference is often so effective that it is tempting not to wonder whether these elites may have been subtle collaborators in the initial opposition. Therefore, using the "networks and know-how of the elites to facilitate the management of projects"91 is also a viable option.

It can be argued that the lack of a robust engagement with elites was a reason for the failure (which led to the cancellation of the World Bank component ${ }^{92}$ ) of the 'Urban Water Sector Reform/Port-Harcourt Water Supply \& Sanitation Project and Third National Urban Water Sector Reform Project'. The project was approved in $2014^{93}$, initially under a cofinancing arrangement between the Government of Rivers State, the African Development Bank, and the World Bank for water sector reforms, rehabilitation, and provision of water in Rivers State. It is worthy of note to mention that the project attracted a good deal of negative publicity and politicization, with the immediate past governor (pre-2015) claiming that the earlier administration of the federal government of Nigeria (pre-2015) was frustrating the government of Rivers State's attempts to secure and access the loan from the African Development Bank (AfDB) and the World Bank ${ }^{94}$. The then-opposition party (now the ruling party) accused the then-government of Rivers State of wanting the loan to fund its electioneering activities, as it was an election period and the incumbent government was serving out its term. ${ }^{95}$ It is interesting to note that at one point the then-governor, although a member of the same political party with the president, eventually decamped to join the opposition party which in time won the election at the national level and became the ruling party in the federal government. The then opposition party at the sub-national level, in Rivers State, won the election to become the ruling party in the state government.

As mentioned earlier and putting the earlier politicization of the project in context, it is not surprising that upon taking over the government, the former opposition party (now the ruling party) exhibited apathy towards the project. Generally, in Nigeria, there is usually a deep distrust of existing civil servants or public officials by a new government if the new ruling party takes over from an opposition party. Hence, it is becoming customary for the incoming government to carry out far-reaching changes to the top management of the civil and public service by engaging in either massive redeployment, early retirement, or termination of employment. ${ }^{96}$ Importantly, the preliminary work for this water project commenced during the preceding administration; these preliminary steps included the legal and related reforms such as

89 Carolyn M. Hendriks and Jennifer Lees-Marshment. "Political leaders and public engagement: the hidden world of informal elitecitizen interaction."page 29. https://researchspace.auckland.ac.nz/bitstream/handle/2292/43583/ful1_Political_Studies_ 14June2018.pdf? sequence $=14 \&$ is Allowed=y . Accessed on 27 October 2020.

90 The Tide, 19 June 2020. "Rivers State Government Warns Against Disruption of Community Projects...Seeks Increased Stakeholder Communication". http://www.thetidenewsonline.com/2020/06/19/rivers-state-government-warns-against-distruption-ofcommunity-projects-seeks-increased-stakeholder-communication/. Accessed on 20 November 2020.

91 Sam Wong. Elite Capture or Capture Elites? Lessons from the 'Counter-elite' and 'Co-opt-elite' Approaches in Bangladesh and Ghana. Page 4. https://www.wider.unu.edu/sites/default/files/wp2010-82.pdf. Accessed on 9 November 2020.

92 The Guardian, 2 September 2020. "Rivers Government, Three Firms Sign Multi-Billion Naira Water Rehabilitation Contracts." https://guardian.ng/property/rivers-government-three-firms-sign-multi-billion-naira-water-rehabilitation-contracts/ ; The World Bank. "Restructuring Paper on a Proposed Project Restructuring of Third National Urban Water Sector Reform Project Approved on April 18, 2014 to Federal Republic of Nigeria, Water Africa" Third National Urban Water Sector Reform Project (P123513), Report No.: RES41250. http://documents1.worldbank.org/curated/en/155661588786022328/pdf/Disclosable-Restructuring-PaperThird-National-Urban-Water-Sector-Reform-Project-P123513.pdf. Accessed on 21 November 2020.

93 The World Bank. “Third National Urban Water Sector Reform Project.” Project ID -P123513 (April 2014). https:// projects.worldbank.org/en/projects-operations/project-detail/P123513 and The African Development Bank. "Nigeria - Urban Water Sector Reform and Port-Harcourt Water Supply and Sanitation Project and the Third National Urban Water Sector Reform Project - P-NG-E00-007 - ESIA" Urban Water Reform \& Port Harcourt WSSP 26 March 2014 https://www.afdb.org/en/projectsand-operations/p-ng-e00-007 < accessed on 21 November 2020>. A project that is to provide accessible clean water to the people in Rivers State including capacity development for public agencies in the sector, it was originally a co-financing arrangement the government of Rivers State, African Development Bank, and World Bank.

94 Business Day News. https://businessday.ng/politics/article/tongue-lashing-federal-government/ > accessed on 21 November 2020.

95 Premium Times. 8 July 2014. "Rivers Government Explains World Bank Loan Blasts PDP”. https://www.premiumtimesng.com/ news/164572-rivers-government-explains-world-bank-loan-blasts-pdp.html. Accessed on 21 November 2020.

96 The Guardian, 1 February 2020. “Court Reinstates Permanent Secretaries Sacked by Wike”. https://guardian.ng/news/court-reinstatespermanent-secretaries-sacked-by-wike/. Accessed on 22 November 2020.> It is pertinent to state that forced or involuntary retirements and sackings of civil servants are unconstitutional and the Nigerian courts have continued to resist the breach of the constitution each time such cases are brought before it. 
setting up the key institutions like the Port Harcourt Water Corporation ${ }^{97}$ and the Rivers State Water Services Regulatory Commission $^{98}$. The project's 'implementation status and results report' ${ }^{99}$, including 'the restructuring paper on a proposed project restructuring ${ }^{100}$, noted that Rivers State was falling behind in its performance; the project was ultimately declared unsuccessful, and the World Bank loan was subsequently cancelled. It can be argued that the government did not give adequate support to the project. Although that does not explain why the African Development Bank component was not also cancelled for poor performance since both loans were contemporaneous for a single project under the cofinancing arrangement ${ }^{101}$. A major component of the project was successfully awarded recently ${ }^{102}$. It is therefore suggested that the African Development Bank applied a more robust stakeholder engagement and management strategy, which argues that an in-depth political awareness ${ }^{103}$ is critical for the success of public projects in Nigeria. The failure of the water project co-funded by the World Bank is not an isolated incident but gradually has become the norm, as projects are stalled, delayed, abandoned and cancelled. The findings by the writer suggests that although the World Bank had a robust stakeholder engagement strategy that is used as a guide for the borrower to adopt, in this instance the World Bank did not monitor and evaluate the application of its stakeholder engagement strategy. Perhaps if the World Bank had done so, it would have adapted its stakeholder engagement strategy when the recurring poor performance became evident in the 'implementation status and results reports' before the cancellation of the project.

\subsubsection{Insufficiency of technical capacity}

Another primary reason for project failure is a lack of capacity. Several studies show that lack of organizational and technical capacity ${ }^{104}$ is responsible for abandonment. It is prevalent in the public sector where there is a dearth of personnel with the requisite skills, experience, and qualifications for procurement specialists, project managers, civil engineers, electrical engineers, design engineers and related professionals. It is important to note that projects have been stalled, failed, and abandoned because of erroneous estimation, inaccurate design, poor risk management, lack of proper planning, poor contract administration, absence of robust project management team and several other related factors; these are the testament to the capacity of the personnel involved in these projects.

\subsection{Grand corruption}

Another major reason identified as a cause of project abandonment is grand corruption. Corruption is Nigeria is a colossus and endemic, as it has permeated down to every stratum of the government and its institutions-it is difficult to isolate any institution that has not been affected. Clearly, the country appears to be jinxed when it comes to good governance and anti-corruption. And the procurement of public projects is where the mammoth perfidy of abuse of public trust is most conspicuous. In the context of this paper, research abounds about the abandonment of projects as a result of grand corruption, which is evidenced by the numerous abandon and failed projects across the country (see table of figures below - with a few pictorial evidence. Sadly, the country was referred to as the global "junk yard of

97 The Port Harcourt Water Corporation Website. https://www.portharcourtwater.ng/about/. Accessed on 21 November 2020.

98 The Rivers State Water Services Regulatory Commission Website. http://www.rswsrc.gov.ng/what-we-do/. Accessed on 21 November 2020 .

99 The World Bank. "Implementation Status \& Results Report." Third National Urban Water Sector Reform Project (P123513). http:/ /documents1.worldbank.org/curated/en/396401592593402275/pdf/Disclosable-Version-of-the-ISR-Third-National-Urban-WaterSector-Reform-Project-P123513-Sequence-No-12.pdf. Accessed on 21 November 2020.

100 The World Bank. "Restructuring Paper on a Proposed Project Restructuring of Third National Urban Water Sector Reform Project Approved on April 18, 2014 to Federal Republic of Nigeria, Water Africa" Third National Urban Water Sector Reform Project (P123513), Report No.: RES41250. http://documents1.worldbank.org/curated/en/155661588786022328/pdf/DisclosableRestructuring-Paper-Third-National-Urban-Water-Sector-Reform-Project-P123513.pdf. Accessed on 21 November 2020.

101 The African Development Bank Group. “The Project Appraisal Report” OWAS Department March 2014. https://www.afdb.org/ fileadmin/uploads/afdb/Documents/Project-and-Operations/Nigeria_-_Urban_Water_Sector_Reform_and_PortHarcourt_Water_Supply_and_Sanitation_Project_-_Appraisal_Report.pdf.Accessed on 21 November 2020.

102 Business Day News. "Rivers Signs 330000 Cubic Litres Water Deal that may give 6200 Jobs" Sept 1, 2020. https://businessday.ng/ lead-story/article/rivers-signs-330000-cubic-litres-water-deal-that-may-give-6200-jobs/<21 November 2020.

103 The Project Management Institute “A Guide to the Project Management Body of Knowledge”, Sixth Edition 2017. Page 376.

104 Charles Ononuju and E.C. Ubani. 'A study of failure and abandonment of public sector-driven civil engineering projects in Nigeria: An empirical review' American Journal of Scientific and Industrial Research, 2013, 4(1): 75-82 Pages 76-77. https://www.scihub.org/AJSIR/ PDF/2013/1/AJSIR-4-1-75-82.pdf ; Benedict Amade, E C Ubani, Francis Amaeshi, and K A Okorocha. "Factors for Containing Failure and Abandonment of Public sector Construction Projects in Nigeria” Journal of Building Performance ISSN: 2180-2106 Volume 6 Issue 1 (2015) pages 73 -74. http://spaj.ukm.my/jsb/index.php/jbp/article/view/143/pdf < accessed on 19 November 2020. 
abandoned and failed projects' ${ }^{105}$ caused by grand corruption. The President of the Chartered Institute of Project Managers of Nigeria ${ }^{106}$, Okoronkwo stated, thus:

'There is much corruption in Nigeria, bothering on abandoned projects and failed projects, and we all know that it is Nigerians and the people that these projects are meant for that normally suffer whenever contracts are awarded to irresponsible, corrupt contractors and corrupt agents.' 107

Also, Page, in the article 'ANew Taxonomy for Corruption in Nigeria' ${ }^{108}$ captured the malady of corruption in projects aptly as follows:

'Malfeasance involving government contracts is perhaps the most common and lucrative type of official corruption in Nigeria today. From multibillion-dollar, presidentially approved infrastructure contracts down to routine requisitions of office supplies, the public procurement process gives kleptocrats many opportunities to enrich themselves and dole out patronage.'

According to Transparency International (TI), “[g]rand corruption is the abuse of high-level power that benefits the few at the expense of the many" ${ }^{109}$; Transparency International went further to note that in extreme cases the whole of the government morphs into a criminal organization using state power for personal enrichment ${ }^{110}$-this assertion is aptly exemplified by the grand corruption in Nigeria. It is noteworthy to mention that an audit carried out by the project audit commission set up by government of Nigeria indicated that there were 11,886 projects abandoned between 1962 to 2012 with an estimated value of 15 trillion Naira ${ }^{111}$; whereas the country's legislature carried out its audit on infrastructural projects from 1999 to 2019 and estimated that over 20,000 projects had been abandoned. Similarly, the Chartered Institute of Project Managers of Nigeria estimated that over 12 trillion Naira ${ }^{112}$ have been wasted due to abandoned projects. Furthermore, the Paradigm Leadership Support Initiative (PLSI), a civil society organization, concluded after studying the country's 2016 audit report that the value of abandoned projects in 2016 was 13.5 billion Naira ${ }^{113}$. Likewise, in $2018^{114}$, PLSI discovered 54 projects worth billions of Naira that were abandoned in Nigeria, whilst it is reported ${ }^{15}$ that Emeka Eze, the former Director General of the Bureau of Public Procurement in 2016 stated that there are over 19,000 abandoned projects all over the country and in 2017 the value of these projects was estimated to be 17 trillion Naira. Currently, according to the PLSI, there are 74 projects valued at 10,984,363,344 Naira which are unaccounted for in the country. The situation is so desperate that corrupt elites under the guise of resuscitating or completing abandoned projects re-award fresh contracts, only to embezzle the funds and abandon the projects again ${ }^{116}$ — some projects are even re-awarded

105 Akande, O.K, Olagunju, R.E, Obiora, O.C, Nsofor, C, Edem-Nse Y.G, Lawal, A.Iyisa, D, Kolo, W. "Evaluation of Failures in Public Projects Management Practices in Minna, Nigeria" Journal of Architecture and Construction Volume 1, Issue 3, 2018, PP 15-24. Page 16. https://www.sryahwapublications.com/journal-of-architecture-and-construction/pdf/v1-i3/2.pdf. < accessed 18 November 2020.

106 Chartered Institute of Project Managers of Nigeria. A statutory organisation for all project managers and the organisation is expected to hold its members accountable for their professional conducts in Nigeria and abroad. https://pm.cipmn.org.ng/about-us/ $<$ accessed on 21 November 2020.

107 Vanguard News, 15 March 2018. "Abandoned, Failed Projects Could Plunge Nigeria into Economic Quagmire - CIPMN". https:// www.vanguardngr.com/2018/03/956222/. Accessed on 21 November 2020.

108 Mathew T. Page. “A New Taxonomy for Corruption in Nigeria”. Carnegie Endowment for International Peace, 2018. Page 20. https://carnegieendowment.org/2018/07/17/new-taxonomy-for-corruption-in-nigeria-pub-76811. Accessed 20 November 2020.

109 The Transparency International Website. "Grand Corruption". https://www.transparency.org/en/our-priorities/grand-corruption\#. Accessed on 22 November 2020.

110 The Transparency International Website. "Grand Corruption". https://www.transparency.org/en/our-priorities/grand-corruption\#. Accessed on 22 November 2020.

111 BudgetIT Nigeria: Cost Of Corruption: The Case of Abandoned Projects in Nigeria. https://medium.com/@BudgITng/cost-ofcorruption-the-case-of-abandoned-projects-in-nigeria-14013b7e1ff3. Accessed on 21 November 2020.

112 The Africa Exponent, 29 May 2019. "Nigeria’s Sad Tale of Abandoned Projects Worth Over 12 Trillion”. https://www.africanexponent.com/ post/10174-nigeria-and-the-curse-of-abandoned-uncompleted-projects. Accessed on 20 November 2020.

113 The Guardian, 24 January 2019. "N14b priority projects awarded, abandoned in 2016 audit report". https://guardian.ng/news/n14bpriority-projects-awarded-abandoned-in-2016-audit-report/. Accessed on 20 November 2020.

114 Paradigm Leadership Support Initiative. Blog, 2 August 2018 "Value for Money Campaign in Infographics 2016 Audit Report." https://plsinitiative.org/value-for-money-campaign-in-infographics-2016-audit-report/. Accessed on 20 November 2020.

115 Onyia Construction: The Extent of Abandoned Construction Projects in Nigeria. http://onyiaconstruction.com/the-extent-ofabandoned-construction-projects-in-nigeria/. Accessed on 20 November 2020.

116 Mathew T. Page. "A New Taxonomy for Corruption in Nigeria”. Carnegie Endowment for International Peace, 2018. Page 23. https:// carnegieendowment.org/2018/07/17/new-taxonomy-for-corruption-in-nigeria-pub-76811. Accessed 20 November 2020. 
numerous times. But they never get completed. Occasionally, as an act of "window dressing," these elites pretend to recommence work by mobilizing work at the site of the abandoned project.

In all this, it is the people that bear the collateral costs of the perfidious act of grand corruption perpetrated by the elites because these abandoned projects were intended to elevate the living standard of the populace, build the capacity of public officials, create an enabling environment (such as ready access to electrical power ${ }^{117}$ ) for businesses to thrive (particularly the micro, small and medium size enterprises), and drive industrialization, ${ }^{118}$ including attracting foreign investment. Projects abandoned range from hospitals to roads, schools, markets, bridges, dams, power generation, and steel manufacturing facilities, to supplies of drugs, healthcare equipment, military hardware, computer, and programs for capacity building training for public officials in all sectors of the economy. The long years of unabated siphoning of funds which have resulted in the abandonment of projects has stifled the economic growth and development of the country. Considering that these projects were meant to stimulate the economy; sadly, that has not been the case and the country has slipped back into another recession, the second in five years ${ }^{119}$ because of a perennially weak economy. Even more worrisome is that the government is broke and has been engaging in massive borrowing ${ }^{120}$ to fund infrastructural development, quite paradoxically because it wasted several trillions of naira in the abandoned and failed projects. Regardless of the obvious monumental corruption, it appears as though these elites are not held accountable as it is expected as such it is continuing unabated and at the same time glamourized ${ }^{121}$, thereby attracting more people into the quagmire of grand corruption — and thus perpetuating the self-inflicted socioeconomic backwardness.

In an article ${ }^{122}$ writing for Brookings Institution, Ngozi Okonjo-Iweala identified the three important enablers of corruption as thus:

'The first is a lack of transparency of critical financial and other information central to economic development, in particular revenues and budgets. Second is the weakness or total absence of institutions, systems, and processes that block leakages. Third is the pervasiveness of impunity_limited political will to hold accountable and punish those found guilty of such corruption.'

To put the problem into the perspective of this paper, it may be argued that an adequate and robust stakeholder engagement of benevolent elites ${ }^{123}$ who are identified as 'believers' ${ }^{124}$, including the primary stakeholders-those directly affected by the project could be a strategy that will contribute to the success of a project, and this can be achieved when stakeholder engagement includes raising the awareness of these stakeholders to available legal and democratic means by which they can hold elites accountable and insist on good governance.

\subsection{Empirical research on abandoned projects in Rivers state}

According to the permanent secretary in Rivers State Ministry of Health, Somiari Harry ${ }^{125}$, the government of Rivers State by a Memorandum of Understanding (MoU) and Shareholders Agreement (SA) with a firm contracted to build a

117 Africa Power Journal, 25 February, 2020. “ Nigeria Settles Disputes over Construction of Mambilla Hydro Plant”. https://www.esiafrica.com/industry-sectors/generation/nigeria-settles-dispute-over-construction-of-mambilla-hydro-plant/ . Mambilla hydro plant was first conceived in the 1970's. < accessed on 20 November 2020.

118 Premium Times. 26 December 2017 “Analysis: Ajaokuta: How Nigeria's Largest Industrial Project Failed”. https:// www.premiumtimesng.com/news/headlines/253680-analysis-ajaokuta-nigerias-largest-industrial-project-failed.html < accessed on 27 November $2020>$ Bidding for building the Ajaokuta Steel Complex was carried out in 1978 with project completion date to be in 1987. Sadly, it yet to be completed.

119 Financial Times. "Nigeria Slumps Back into Recession". https://www.ft.com/content/ea70f0b4-5f13-423b-b1ed-6d6c424d1b91 Accessed on 21 November 2020

120 Proshare Intelligent Investing: Nigeria Ballooning Debt Profile. https://www.proshareng.com/news/NIGERIA\%20ECONOMY/ Nigeria-s-Ballooning-Debt-Profile/54146. Accessed on 21 November 2020.

${ }^{121}$ Adeola, G. T (2008). Military Legacies and the Challenge of Managing Diversities in Nigeria's Federation. A Paper Presented to the $20^{\text {th }}$ Summer University Programme of the Institute of Federalism, Fribourg, Switzerland.

122 Ngozi Okonjo-Iweala. 'Strategies for Winning the Fight against Corruption' Foresight Africa. Top Priorities for the Continent in 2019. A Brookings Growth Initiatives at Brookings Page 17, https://www.brookings.edu/blog/africa-in-focus/2019/01/15/strategiesfor-winning-the-fight-against-corruption/. Accessed on 20 November 2020

123 The World Bank. "CDD and Elite Capture: Reframing the Conversation." Social Development How to Series Vol. 3. February 2008 Page 2. http://documents1.worldbank.org/curated/zh/397181468137726436/pdf/430830BRI001NO1 ing0the0Conversation.pdf. Accessed 9 November 2020,

124 Eleni Panopoulou, Efthimios Tambouris, Konstantinos Tarabanis (CERTH): Stakeholder Community for Once-Only Principle: Reducing Administrative Burden for Citizens "Strategic stakeholder engagement plan (D2.2)". Version 1.4. (25 May 2019). Ref. Ares (2019)3552739 - 02/06/2019 Page 67. https://ec.europa.eu/research/participants/documents/downloadPublic?documentIds= 080166e5c48ab206\&appId=PPGMS. Accessed 22 November 2020

125 The Guardian, 11 September 2014. "How Rivers wasted N8.54b on Karibi Whyte hospital, by Perm Sec". https://guardian.ng/news/ how-rivers-wasted-n8-54b-on-karibi-whyte-hospital-by-perm-sec/. Accessed on 22 November 2020 
1000-bed specialist hospital estimated at $\$ 98 \mathrm{mn}$. The contractual arrangement for the implementation of the project appears to be a public private partnership (PPP), however, based on the MoU and SA the government paid the firm \$39.2 mn (equivalent to 4.6 bn Naira in 2008) which was $40 \%$, the equity of the government in the project. However, the firm demolished an existing hospital in the proposed site and thereafter discontinued work, and the government did not take any action, but rather entered another contract with a sister company of the initial firm for the same project at a value of $\$ 150 \mathrm{mn}$ and paid an additional 3.94 billion Naira being $20 \%$ of the US\$150 million. Thus, the funds paid for the proposed hospital totaled N8.54 bn. The project was abandoned, however, the then-opposition party stated it was being reawarded for $\$ 300 \mathrm{mn}^{126}$ which gave the elites in government another opportunity to siphon funds from the project. ${ }^{127}$

Likewise, the previous government contracted with a firm to build a monorail of about $2.6 \mathrm{~km}^{128}$, which would have been completed at the cost of $\$ 400 \mathrm{mn}^{129}$ before the end of the term of the government. Curiously, the technical partners who have been paid 22 bn Naira for its service, when testifying before a judicial panel of enquiry, stated the project was no longer tenable ${ }^{130}$. The monorail project was designed to cover $12 \mathrm{~km}$ at the cost of $50 \mathrm{bn}$ Naira, but it was abandoned by the succeeding government.

Another monumental, abandoned project is an auto destruct syringe factory set up by a former governor of the State-who secured injunctive relief restraining the Economic and Financial Crime Commission (EFCC) from arresting, arraigning, and prosecuting him for fraud. ${ }^{131}$ It was reported that the present government had stated that the preceding government spent 36 bn Naira for the expansion of the company, yet the factory is not in operation. Because of this, a judicial panel was set up to investigate the apparent misappropriation of the funds. ${ }^{132}$

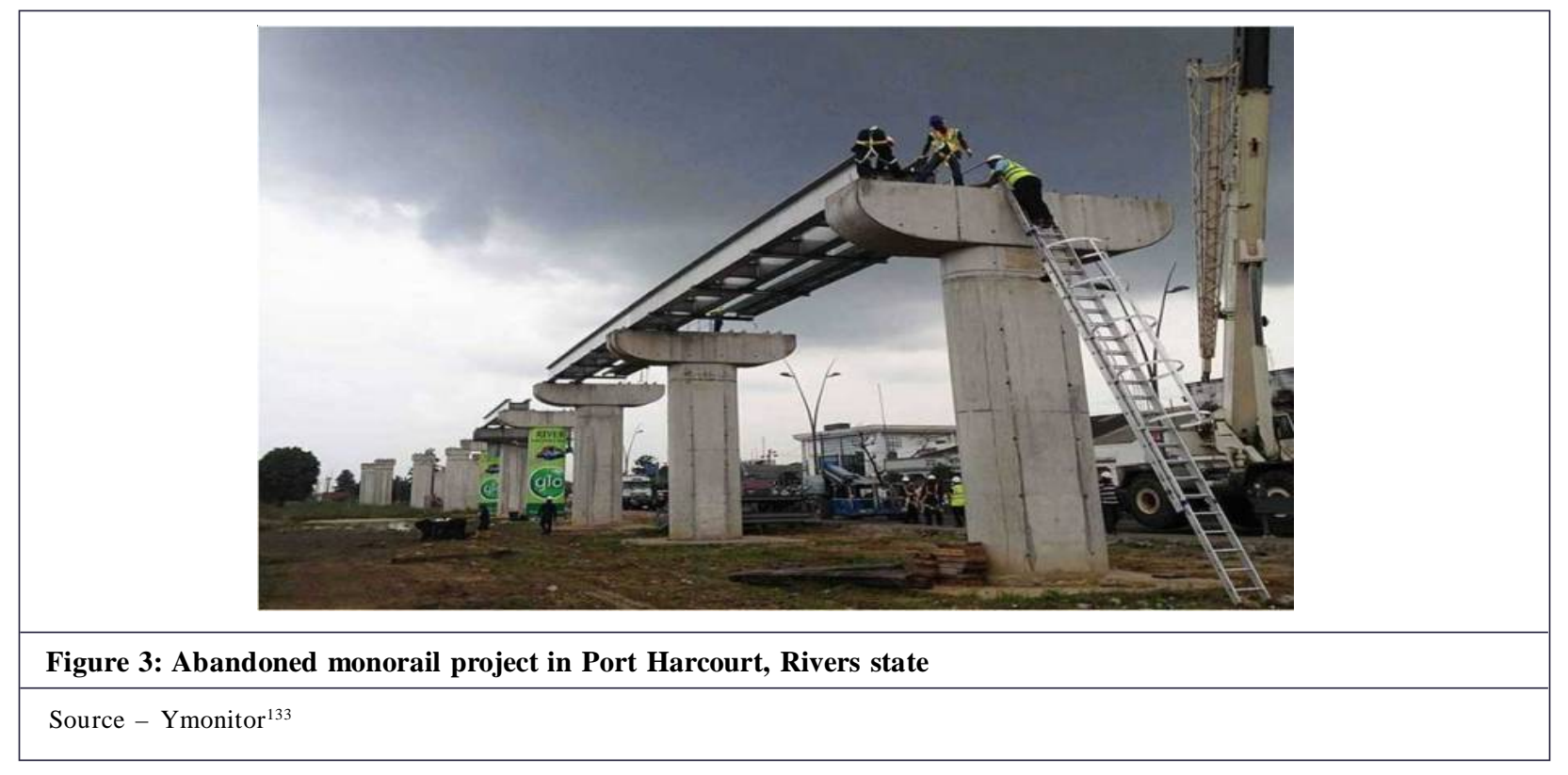

${ }^{26}$ The Nigerian Voice, 10 February 2015. "PDP [People Democratic Party] Queries Taking Over of Karibi Whyte Hospital by a Chinese Company". https://www.thenigerianvoice.com/movie/169510/pdp-queries-taking-over-of-karibi-whyte-hospital-by-achines.html. Accessed on 22 November 2020.

${ }_{127}$ Mathew T. Page. “A New Taxonomy for Corruption in Nigeria”. Carnegie Endowment for International Peace, 2018. Page 23. https:/ /carnegieendowment.org/2018/07/17/new-taxonomy-for-corruption-in-nigeria-pub-76811. Accessed 20 November 2020.

128 Mathew T. Page. “A New Taxonomy for Corruption in Nigeria”. Carnegie Endowment for International Peace, 2018. Page 12. https:/ /carnegieendowment.org/2018/07/17/new-taxonomy-for-corruption-in-nigeria-pub-76811. Accessed 20 November 2020.

129 The Point Blank, 28 March 2016. "Why I Won’t Touch Amaechi’s Rivers Monorail- Wike". http://pointblanknews.com/pbn/ exclusive/wont-touch-amaechis-rivers-monorail-wike/. Accessed on 22 November 2020.

130 The Guardian, 25 August 2015. "Rivers Monorail Project No Longer Tenable after Gulping N33.9b, Says Technical Partner." https://guardian.ng/news/rivers-monorail-project-no-longer-tenable-after-gulping-n33-9b-says-technical-partner/. Accessed on 21 November 2020.

131 The Guardian, 19 March 2020. “Odili Approaches Court as EFCC Begins Probe of Alleged N100b fraud”. https://guardian.ng/news/ odili-approaches-court-as-efcc-begins-probe-of-alleged-n100b-fraud/ < accessed on 21 November 2020.

132 Vanguard, 15 November 2018. "Rivers govt to probe mgt of N36bn under Amaechi”. https://www.vanguardngr.com/2018/11/riversgovt-to-probe-mgt-of-n36bn-under-amaechi/. Accessed on 21 November 2020.

133 Picture of the abandoned Monorail. https://i2.wp.com/monitor.ynaija.com/wp-content/uploads $/ 2017 / 04 /$ monorail-project.jpg?resize= 696\%2C459\&ssl=1. Accessed on 27 November 2020. 


\subsubsection{Some abandoned projects across Nigeria}

Ajaokuta steel foundation was laid in 1980 and after spending $\$ 10$ bn Naira the project is yet to be completed ${ }^{134}$

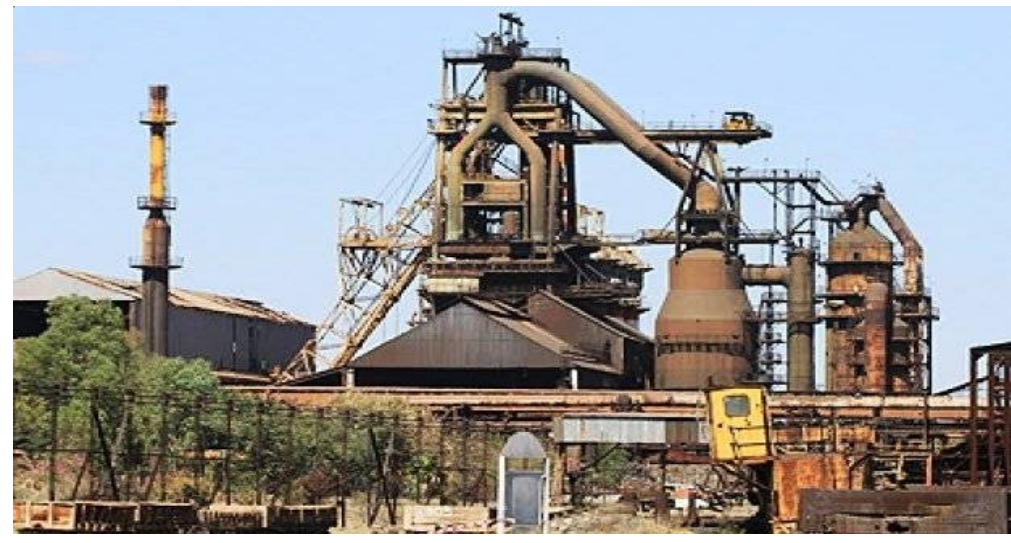

Figure 4: Ajaokuta steel company

(C) Source- Premium Time

\section{Optimal utilization of stakeholder engagement guidelines}

As mentioned earlier in the paper, the MDIs have substantial knowledge-based resources on practically all issues they have encountered in their operations, and as such, they operate from a real wealth of experiential lessons. One such body of lessons learned is reflected in the MDIs' stakeholder engagement strategies, specifically, with elites in borrower nations. The elites are powerful stakeholders and often use their influence and power for personal gain by hijacking projects, thereby denying the majority of the beneficiaries the output of the projects. In recognition of this fact, the MDIs are circumspect about actively engaging or giving active roles in projects to the elites, in order to forestall any occurrences of elite capture. To achieve this, MDIs tend to clearly limit the extent of the elite engagements ${ }^{135}$ without undermining their importance in the overall strategy for achieving success in the projects, using the stakeholder analysis and matrix. The efforts to engage the elites in a measured way are in addition to community engagement, through which the scope of engagement is wider, and the beneficiaries are empowered through training and technology either to hold the elites accountable or to get their voices heard regarding the project.

Based on the foregoing, it is clear that less-than-robust approaches to stakeholder engagement could be blamed, in part, for failed or unsuccessful projects. Although engagement of any stakeholder should be continuous throughout the life cycle of a project ${ }^{136}$, the level of engagement and style will differ according to the rise or fall of each stakeholder's "salience" (prominence and importance) among the target group of individuals or entities. ${ }^{137}$

Furthermore, there should be different levels of communications or messages with the elites - the core and the customized. The core should include the key features of the project, whilst the customized should turn on the position and perception of the stakeholder. The Asian Development Bank (ADB) in its stakeholder communication strategies guidance note ${ }^{138}$ emphasized the importance of how the message is to be conveyed, and hence sorted those messages into two categories - core and customized. The core message focuses on the key features of the project, whilst the customized is focused on the stakeholder albeit to give the right information or clarification, thus:

134 Premium Times. 26 December 2017 “Analysis: Ajaokuta: How Nigeria's Largest Industrial Project Failed”. https:// www.premiumtimesng.com/news/headlines/253680-analysis-ajaokuta-nigerias-largest-industrial-project-failed.html < accessed on 27 November 2020.

135 Robert R. Bianchi and Sherrie A. Kossoudji. "Interest Groups and Organizations as Stakeholders" World Bank Social Development Papers Paper Number 35, June 2001. Page 2. http://documents1.worldbank.org/curated/en/295541468780869754/pdf/ 283220SDP135.pdf < accessed 22 November 2020.

136 The World Bank. "Guidance Note for Borrowers. Environmental \& Social Framework for IPF Operations. ESS10: Stakeholder Engagement and Information Disclosure" First Edition, published June 2018. http://documents1.worldbank.org/curated/en/ 476161530217390609/ESF-Guidance-Note-10-Stakeholder-Engagement-and-Information-Disclosure-English.pdf . Accessed on 18 August 2020.

137 Kvam, Reidar. "Meaningful Stakeholder Engagement: A Joint Publication of the Multilateral Financial Institutions Group on Environmental and Social Standards." Page 4. The Inter-American Development Bank Publicatio. https://publications.iadb.org/ publications/english/document/Meaningful_Stakeholder_Engagement_A_Joint_Publication_of_the_MFI_ Working_Group_on_Environmental_and_Social_Standards_en.pdf. Accessed on 15 June 2020.

138 Asian Development Bank. "Guidance Note on Stakeholder Communication Strategies for Projects in South Asia" Institutional Document, No. 3 June 2019. Page 6. http://dx.doi.org/10.22617/TIM190189-2. Accessed on 10 August 2020. 
"For stakeholders who openly support the project, the core message may suffice. For those who have complaints or who oppose the project, the customized message will depend on the reasons for their opposition. For example, if the reason is misperception or inadequate information, then the message will be on providing the correct information or agreeing with the stakeholder on how to determine the right information. If the reason is mistrust of the project proponent, then the message could be on the project's standards or measures to ensure transparency and accountability of the project proponent and on seeking stakeholder's suggestions on how to improve this. If the reason is expected non-satisfaction of their substantive, procedural, and psychological needs..., then the message could be on measures to address [the] needs and interests of affected stakeholders as well as the project's limitations, and suggestions of stakeholders on how the project could address these needs."139

According to the strategy exemplified in the "Different levels and approaches to stakeholder engagement" of the AA Stakeholder Engagement Standard (2015), the elites should always be placed in the middle and high categories with regards to the 'Communication' 'Level of Engagement' and 'Nature of Relationship'. It will be observed that the methods of engagement for these categories-inform, transact, consult, negotiate, involve, and collaborate are all components of a robust engagement strategy. It is also a sound practice to empower the primary stakeholder or the community through advocacy, awareness raising, training, and provision of tools for good governance, to enable them to participate, monitor the activities of these elites as regards public projects. This, the MDIs may do directly or indirectly by supporting the experienced and genuine civil society organizations in the country.

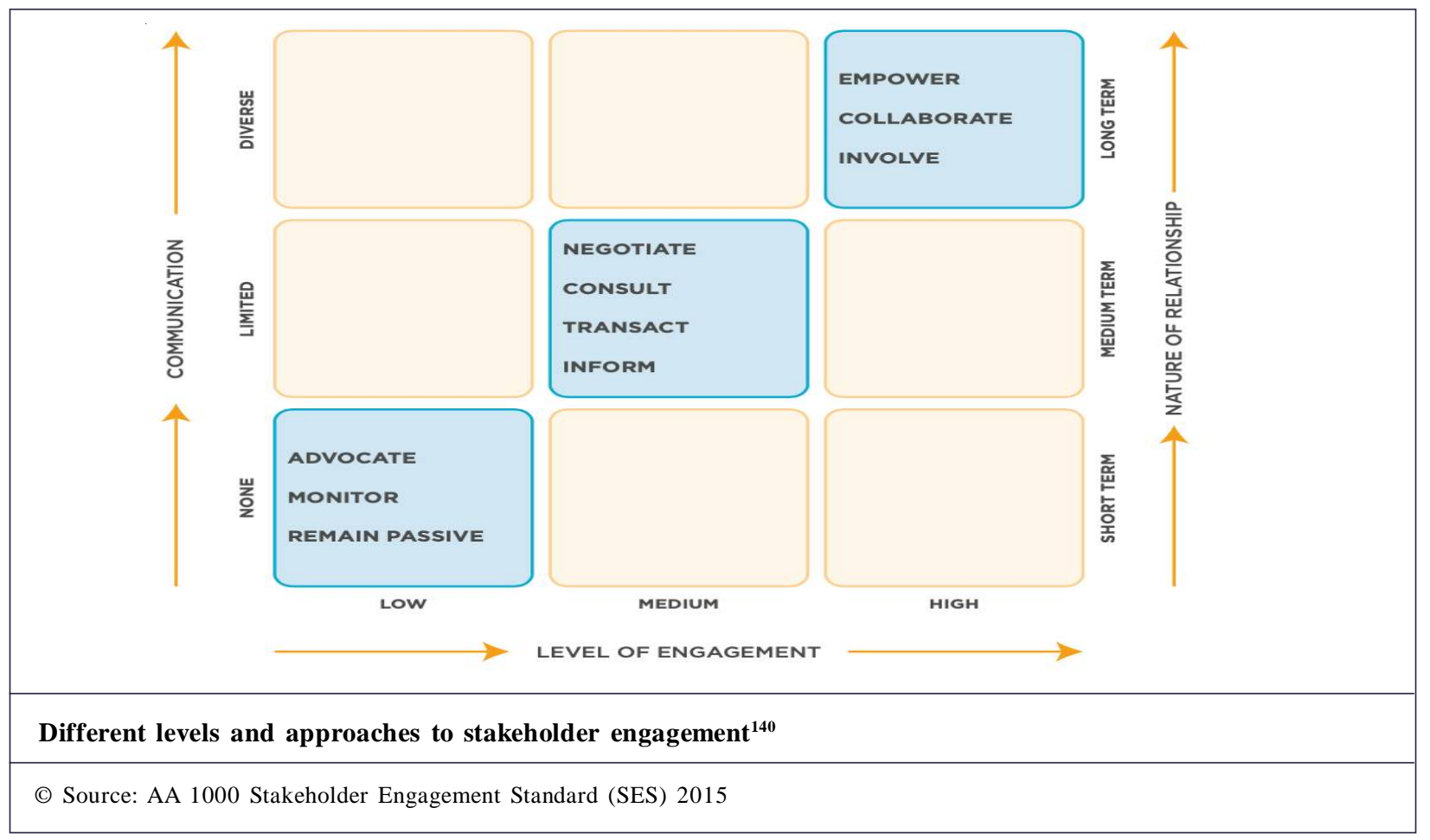

\section{Conclusion}

Stakeholder engagement should be as dynamic and variable as the individuals or entities being engaged; it should not be static but adaptive to circumstances as they arise. Engagement with the relevant elites should be undertaken without compromising the core objectives of a project and fundamental principles of public procurement-transparency, integrity, value for money, and fitness for purpose. Because the abuse of power is an omnipresent risk ${ }^{141}$, once projects have been conceptualized and risk management measures ${ }^{142}$ put in place, it is imperative to apply behavioral sciences and predictive

139 Asian Development Bank. "Guidance Note on Stakeholder Communication Strategies for Projects in South Asia" Institutional Document, No. 3 June 2019. Page 6. http://dx.doi.org/10.22617/TIM190189-2. Accessed on 10 August 2020.

140 AA1000 Stakeholder Engagement Standard (SES) 2015, AccountAbility Publication. Page 21. https://www.accountability.org/ static/940dc017198458fed647f73ad5d47a95/aa1000ses_2015.pdf. Accessed 14 November 2020.

141 Rasmus Broms, Carl Dahlström and Mihály Fazekas "Political Competition and Public Procurement Outcomes." Comparative Political Studies Journal, February 21, 2019; Vol. 52(9). Page 1260."

142 AA1000 Stakeholder Engagement Standard (SES) 2015, AccountAbility Publication, page 15. https://www.accountability.org/ static/940dc017198458fed647f73ad5d47a95/aa1000ses_2015.pdf. Accessed 14 November 2020. 
analytics when dealing with political risks, especially those presented by the elites. It is suggested the genuine civil society organization should be engaged to help with advocacy to increase community participation and awareness. And training to empower primary stakeholders to demand accountability from the elites if they are not part of the decisionmaking process, to encourage whistleblowing and provide technological tools so that corruption can be reported in real-time. The design and implementation of projects should take into consideration the political nuances that exist within the given area because often there are "Design-reality gaps' between expectations and on-the-ground realities" 143 .

Another strategy to mitigate the corrosive influence of local elites' is for the MDIs to nudge the government towards using PPPs as special purpose vehicles for implementing projects under co-financing or wholly funded arrangements. Especially where there is a lack of technical capacity within the public service to implement the procurement and project. It is suggested that the use of a PPP should be a mandatory requirement for a grant or loan application to the MDIs. Additionally, the counterpart fund for PPPs or co-financing arrangements should be disbursed on behalf of the state (sub-national) by the federal (national) government from the federation account to demotivate rent-seeking elites from frustrating or hijacking the project.

Therefore, when dealing with an elite, it will be immensely helpful to ponder on these pertinent questions stated in the 'Understanding Stakeholder Thinking: Themes from a Finnish Conference' as they are germane to the effective stakeholder engagement, thus:

"Five key questions may be asked by managers to capture the information essential for effective stakeholder management: Who are our stakeholders? What are their stakes? What opportunities and challenges do our stakeholders present to the firm? What responsibilities (economic, legal, ethical, and philanthropic) does the organization have to its stakeholders? What strategies or actions should the firm take to best respond to stakeholder challenges and opportunities?"144

Stakeholder engagement has gone beyond the provision of technical tools and solutions in the form of templates, manuals, guidelines, and checklists. It has become necessary to include data analysis and spend analytics as tools to trigger behavioral changes on the part of the affected elites, nudging ${ }^{145}$ them in the direction that will guarantee commitment to the implementation of the projects, in addition to vigorous supervision to ensure performance. Furthermore, considering that government policies and objectives are typically in a state of flux whenever there is a transition to a new government (this is certainly true in Nigeria), a robust engagement strategy that anticipates and embraces these changes with preparedness does make progress in project implementation, particularly, in international development projects where incoming administrations cannot exert undue influence ${ }^{146}$.

As noted earlier, there is an acute gap in literature focused on the engagement of political elites in projects funded by MDIs. Studies have shown that it is counterproductive to engage elites beyond the preliminary stages of the projects requiring advocacy and policy reforms to create an enabling environment for the implementation. Because these local elites may capture the projects for their selfish interest ${ }^{147}$ and they often lack technical and professional capacity. Other weaknesses in this work will be the misconception that state (sub-national) government will support the complete control of management or disbursement of the grant or loan by the federal (national) government beyond deduction from the federation account for repayment. In the past, attempts by the federal (national) government to have complete

143 Petra Burai. "Overcoming the pitfalls of engaging communities in anti-corruption programmes" in Saul Mullard (ed.) Chr. Michelsen Institute (CMI). U4 Issue 2020:3 Pages 14-15. https://www.u4.no/publications/overcoming-the-pitfalls-of-engagingcommunities-in-anti-corruption-programmes.pdf < accessed on 22 November, 2020.

144 Archie. B. Caroll and Juha Nasi, "Understanding Stakeholder Thinking: Themes from a Finnish Conference”. Business Ethics 6 (1):46-51 (1997), page 47. https://www.academia.edu/860778/Understanding_Stakeholder_Thinking_Themes_From_a_ Finnish_Conference. Accessed on 28 August 2020.

145 Richard H. Thaler and Cass R. Sunstein. "NUDGE Improving Decisions About Health, Wealth, and Happiness" Yale University Press, New Haven, \& London, 2008. Page 97.

146 Eleni Panopoulou, Efthimios Tambouris, Konstantinos Tarabanis (CERTH): Stakeholder Community for Once-Only Principle: Reducing Administrative Burden for Citizens "Strategic stakeholder engagement plan (D2.2)". Version 1.4. (25 May 2019). Ref. Ares (2019)3552739 - 02/06/2019 Page 66. https://ec.europa.eu/research/participants/documents/downloadPublic?documentIds $=080166 \mathrm{e} 5 \mathrm{c} 48 \mathrm{ab206} \& \mathrm{appId}=$ PPGMS . Accessed 22 November 2020.

147 Michael K. Musgrave and Sam Wong. "Towards a More Nuanced Theory of Elite Capture in Development Projects. The Importance of Context and Theories of Power." Journal of Sustainable Development. Vol. 9, No. 3 (2016). http://www.ccsenet.org/journal/ index.php/jsd/article/view/57442. Accessed 15 December 2020.>. Page 92. 
fiscal control have met stiff resistance from state (sub-national) governments on the grounds that Nigeria is practising federalism ${ }^{148}$. Similarly, the suggestion that elites should be adequately engaged is susceptible to elite capture and grand corruption because the country is perpetually at the bottom of the Corruption Perceptions Index (CPI) ${ }^{149}$.

\section{Future Scope}

In the United States and Europe (with the exception of a few countries), because of the quality of their democracies, there is accountability, a high standard of good governance, strong and depersonalized institutions where irresponsible behaviors "get punished either formally or informally" ${ }^{150}$. As such, there is little or no need to rely on elites' engagement to implement projects. However, in Nigeria, the exact opposite exists as the prevailing political economy ${ }^{151}$ does not support good governance, accountability, and anti-corruption, the MDIs should enlist or increase support for credible institutions (formal and informal) and civil society organizations advocating for democracy, good governance and reforms, which will train and empower citizens with resources to become actively involved in their development, and to hold public officials (elected or appointed) to account for their actions ${ }^{152}$. It is worth noting that there is a strong linkage between the empowered citizenry and civic participation or engagement. The effectiveness of the recent EndSARS protest $^{153}$ in parts of Nigeria showed how young citizens empowered through information technology mobilized (civic participation) to demand police reforms, although the protest was brutally suppressed. ${ }^{154}$

A broader strategy is to fund projects using a third party where the control of the funds is passed on to the third party-the PPP or joint venture, which in effect transfers the political and performance risks posed by meddlesome elites $^{155}$.

\section{Mona Frøystad, Kari K. Heggstad and Odd Helge Fjeldstad (citing Nash et al) stated ${ }^{156}$}

"For development actors seeking to influence policy, political context matters because it determines the feasibility, appropriateness and effectiveness of their actions."

The above assertion resonates with the current situation in Nigeria where meddlesome elites often interfere with development projects. Against this backdrop, more studies are needed within the context of Nigeria to find strategies that will offer the right balance between leveraginging the influence of political elites to achieve sustainable development and the risk of elite capture of development projects.

148 Financial Times, 29 Sept 2010. "Excess crude account: Rainy day fund runs dry". https://www.ft.com/content/0a7935ae-ca9711df-a860-00144feab49a. Accessed on 17 December 2020.

149 Transparency International. "Corruption Perceptions Index". https://www.transparency.org/en/cpi/2019/results. Accessed on 16 December 2020.

150 Mike Balthazar Beke. "Political influence in public procurement: balancing between legality and illegality", PhD thesis (Universidad Complutense De Madrid Facultad De Ciencias Políticas Y Sociología, 2017) Page 54. https://baselgovernance.org/sites/default/ files/2020-03/Mike\%20Beke_Political\%20influence\%20in\%20public\%20procurement_2018_0.pdf. Accessed on 17 December 2020.

151 Mona Frøystad, Kari K. Heggstad and OddHelge Fjeldstad, Chr. Michelsen Institute (CMI). "Linking procurement and political economy." Page 3. Report Commissioned by the World Bank Institute and DFID, 2010. https://www.cmi.no/publications/file/3955linking-procurement-and-political-economy-a-gui.pdf. Accessed on 17 December 2020.

152 Department for International Development and Ian MacAuslan. "India's National Rural. Employment Guarantee Act: A Case Study for How Change Happens. "Empowering Poor People and Strengthening Accountability" Page1\& 2. 2008: Oxfam. https:/ /assets.publishing.service.gov.uk/government/uploads/system/uploads/attachment_data/file/67465/empower-account-summarynote.pdf < accessed on 18 December 2020.

153 Oluwole Ojewale. The Brookings Institution, Thursday, October 29, 2020. "Youth protests for police reform in Nigeria: What lies ahead for \#EndSARS". https://www.brookings.edu/blog/africa-in-focus/2020/10/29/youth-protests-for-police-reform-in-nigeria-whatlies-ahead-for-endsars/ < accessed on 17 December 2020.

154 Ruth Maclean. The New York Times, 13 Nov 2020. "Nigeria Goes on Offensive against Youth Protesting Police Brutality”. https:/ /www.nytimes.com/2020/11/13/world/africa/Nigeria-EndSARS-protests.html < accessed on 17 December 2020.

155 Organisation for Economic Co-operation and Development and Association of Southeast Asian Nations. "Risk Mitigation Instrument for Political Risks". https://rmid-oecd.asean.org/project-risks-mitigation/risk-mitigation-instruments/political-risk-mitigation/riskmitigation-instrument-for-political-risks/. Accessed on 17 December 2020.

156 Mona Frøystad, Kari K. Heggstad and OddHelge Fjeldstad, Chr. Michelsen Institute (CMI). "Linking procurement and political economy." Page 3. Report Commissioned by the World Bank Institute and DFID, 2010. https://www.cmi.no/publications/file/3955linking-procurement-and-political-economy-a-gui.pdf. Accessed on 17 December 2020>. Accessed on 17 December 2020

Citethis articleas: Soala M ercy Sam Warmate(2021). Stakeholder management in public procurement: Rethinking the engagement strategy for cofinancing in Rivers state, Nigeria. International Journal of M anagement Research and Economics. 1(3), 22-43. doi: 10.51483/ IJ MRE.1.3.2021.22-43. 